\title{
Article
}

\section{Sharia Supervisory Boards, Governance Structures and Operational Risk Disclosures: Evidence from Islamic Banks in MENA Countries}

Ahmed, Elamer A., Ntim, Collins G., Abdou, Hussein and Pyke, Chris Available at http://clok.uclan.ac.uk/29357/

Ahmed, Elamer A., Ntim, Collins G., Abdou, Hussein ORCID: 0000-0001-55801276 and Pyke, Chris ORCID: 0000-0001-6576-2709 (2019) Sharia

Supervisory Boards, Governance Structures and Operational Risk Disclosures: Evidence from Islamic Banks in MENA Countries. Global Finance Journal . ISSN 1044-0283

It is advisable to refer to the publisher's version if you intend to cite from the work. http://dx.doi.org/10.1016/j.gfj.2019.100488

For more information about UCLan's research in this area go to http://www.uclan.ac.uk/researchgroups/ and search for <name of research Group>.

For information about Research generally at UCLan please go to http://www.uclan.ac.uk/research/

All outputs in CLoK are protected by Intellectual Property Rights law, including Copyright law. Copyright, IPR and Moral Rights for the works on this site are retained by the individual authors and/or other copyright owners. Terms and conditions for use of this material are defined in the policies page. 
Full reference: Elamer, A.A., Ntim, C.G., Abdou, H.A., \& Pyke, C. (2019) 'Sharia Supervisory Boards, Governance Structures and Operational Risk Disclosures: Evidence from Islamic Banks in MENA Countries', Global Finance Journal, Forthcoming (Accepted 27 July 2019).

\section{Sharia Supervisory Boards, Governance Structures and Operational Risk Disclosures: Evidence from Islamic Banks in MENA Countries}

Ahmed A. Elamer ${ }^{a *}$, Collins G. Ntim ${ }^{\text {b }}$, Hussein A. Abdou ${ }^{\mathrm{c}}$, and Chris Pyke ${ }^{\mathrm{d}}$

${ }^{a}$ Brunel Business School, Brunel University London, Kingston Lane, Uxbridge, London, UB8 3PH $\mathrm{UK}$; and

Department of Accounting, Faculty of Commerce, Mansoura University, Mansoura, Egypt

Email: ahmed.a.elamer@gmail.com

*Corresponding author

${ }^{\mathrm{b}}$ Department of Accounting, Centre for Research in Accounting, Accountability and Governance, Southampton Business School, University of Southampton, Southampton, SO17 1BJ, UK Email: C.G.Ntim@soton.ac.uk

${ }^{c}$ Lancashire School of Business and Enterprise, University of Central Lancashire, Preston, PR1 2HE, $\mathrm{UK}$; and

Department of Management, Faculty of Commerce, Mansoura University, Mansoura, Egypt Email: habdou@uclan.ac.uk

${ }^{\mathrm{d}}$ Lancashire School of Business and Enterprise, University of Central Lancashire, Preston, PR1 2HE, UK

Email: cpyke2@uclan.ac.uk

*Corresponding author; Address for correspondence: Brunel Business School, Brunel University London, Kingston Lane, Uxbridge, London, UB8 3PH UK. Tel: +44 (0) 127423 4930; E-mail: ahmed.elamer@brunel.ac.uk and/or ahmed.a.elamer@ gmail.com. 


\title{
Sharia Supervisory Boards, Governance Structures and Operational Risk Disclosures: Evidence from Islamic Banks in MENA Countries
}

\begin{abstract}
This paper examines the impact of Sharia supervisory board (SSB) and governance structures on the extent of operational risk disclosures (ORDs), using a sample of 63 Islamic banks from 10 (i.e., Bahrain, Egypt, Jordan, Kuwait, Lebanon, Oman, Qatar, Saudi Arabia, Syria, and the UAE) countries in the Middle East and North Africa (MENA) region for the fiscal years 2006 to 2013. Drawing on Sharia compliance, Islamic banking and corporate governance literature, our findings are as follows. We find that SSB, block ownership, board independence, and country-level governance quality are statistically significant and positively associated with ORDs. Our results are robust when controlling for several bank- and country-level variables. Our study has implications for policy-makers and regulators in the MENA region with respect to the development and implementation of SSB and governance mechanisms that can improve operational risk disclosures. Finally, the findings highlight the need to enhance current understanding of SSB structures and governance mechanisms that can best help Islamic banks towards engaging in effective compliance with recent governance and accounting reforms.
\end{abstract}

Keywords: Operational Risk Disclosure; Sharia supervisory board; Corporate Governance; Country Governance; Islamic Banks; MENA countries

JEL classification: G21, G32, G34, G38, M48 


\section{Introduction}

The observable weaknesses in operational risk management and disclosure practices, as well as corporate governance $(\mathrm{CG})$ structures in the wake of the financial crisis have reignited the debate relating to the importance of managing operational risk within the banking sector worldwide (Barakat \& Hussainey, 2013; BCBS, 2014; Elamer et al., 2019). Similarly, previous studies that have examined the failure of many conventional banks (e.g., RBS), as well as Islamic banks (IBs) (e.g., the Dubai Islamic Bank) have identified weaknesses in CG, risk management, and disclosure practices, as potential drivers of the recent global banking crisis (BCBS, 2014, 2014d; Elamer et al., 2018; Elamer \& Benyazid, 2018; Ntim et al., 2013). Meanwhile, a good number of past studies have explored a number issues in IBs, including (i) performance of IBs in comparison with their conventional counterparts (e.g., Mallin et al., 2014); (ii) CG and performance (e.g., Mollah \& Zaman, 2015); (iii) CSR, ethics and performance (e.g., Farook et al., 2011; Mallin et al., 2014); (iv) voluntary disclosure (e.g., AIBassam \& Ntim, 2016; Haniffa \& Hudaib, 2007), and normative and critical evaluations (e.g., Safieddine, 2009), among others. However, and notwithstanding its importance, prior studies investigating the association between CG and operational risk disclosures (ORDs) within banks generally, and in Islamic banks, in particular, are rare (Barakat \& Hussainey, 2013).

More importantly, prior literature has not examined the crucial question of how Sharia supervisory boards (SSBs), other bank-level governance mechanisms, and country-level governance structures may influence ORDs of IBs. Therefore, this paper explores the impact of these three types of governance structures on ORDs of IBs using a natural and unique corporate setting in the Middle East and North Africa (MENA) region, where recent CG and regulatory reforms, including the implementation of the Basel accords (e.g., I, II and III), IAS 32 and 39, 
as well as IFRS 7 and 9 in particular, require banks to provide more transparent information about their operational risk practices (Bischof, 2009).

Generally, IBs may engage in comprehensive ORDs for a number of theoretical reasons. First, agency theory suggests that effective and transparent ORDs can mitigate agency costs between insiders (management) and shareholders, and thus impact positively on the performance of IBs (Jensen \& Meckling, 1976). Second, signalling theory predicts that IBs communicate operational risk information to outsiders in order to signal to potential investors the banks' apparent sound operational risk management practices and performance, and hence reducing information asymmetry between insiders and outsiders (Connelly et al., 2011). Third, from the legitimacy theory stance, engaging in increased ORDs, including those relating to Sharia, can be considered a strategic way in which IBs can legitimise their operations and gain acceptance within the broader society (Connelly et al., 2011). Fourth, resource dependence theory predicts that increased ORDs can help in granting IBs access to essential resources, such as finance and contracts that can facilitate their long-term survival (Elamer et al., 2019; Pfeffer \& Salancik, 2003).

Accordingly, previous studies have concentrated on the incentives of, and explanations for, the incidence and amount of ORDs. For instance, Barakat and Hussainey (2013) examined the connections among CG, regulatory quality and ORDs in European banks. They argue that banks characterised by a greater percentage of NEDs, fewer executive shareholding and concentrated private shareholding offer greater ORDs. Relatedly, Abdallah et al. (2015) argue that Islamic financial institutions disclose fewer risks than those of non-Islamic financial institutions because they are inherently conservative institutions, when it comes to risk. Additionally, Izhar and Asutay (2010) argue that operational risks (e.g., Sharia incompliance 
risk) are considered the second most important risks in IBs after credit risk. Nevertheless, prior studies arguably suffer from a number of limitations.

First, prior studies examining the nature and determinants of ORDs in IBs are either limited or qualitative in nature (Abdallah et al., 2015). Second, prior studies which address ORDs have mostly been done in developed countries (Barakat \& Hussainey, 2013; Helbok \& Wagner, 2006) and cross-country studies are notably scarce (Abdallah et al., 2015). Third, to the best of our knowledge, there is no evidence on whether and, if so, how Islamic governance and country-level governance qualities are associated with ORDs in different regulatory environments, particularly within MENA IBs. Of a direct relevance to our current study, however, is Neifar and Jarboui (2018). Using data from 34 Islamic banks from Asia over a period from 2008 to 2014, Neifar and Jarboui (2018) found that independent directors and ownership concentration have a positive impact on operational risk disclosure. Conversely, they found that CEO duality and SSB have a negative relationship with operational risk disclosure. However, Neifar and Jarboui (2018) suffer from a number of limitations. First, their sample is from different countries (Saudi Arabia, Malaysia, and Iran) with different economic, political and social backgrounds, but we have carefully chosen a homogenous sample from MENA countries. In addition, they failed to control for potential country-level differences by including country level variables, such as country-level governance and corruptions that can arguably affect the levels of operational risk disclosures. Finally, they used the mere presence of a SSB as a proxy for Islamic governance. We extend and complement this line of research by considering several governance attributes by (i) expanding our sample from 34 to 63 IBs from a fairly homogenous economic, geographical and political areas; (ii) adding country-level governance quality variable in addition to other country-level control variables, as unique variables to explain the key differences among the different countries sampled. Against this background, we contend that the level and extent of ORDs can be expected to differ from those of conventional banks. As such, studying the ORDs in IBs, where empirical findings are rare, 
can contribute towards improving current knowledge and understanding of the motives and determinants of good ORD practices.

Consequently, the current study seeks to extend, as well as make a number of new contributions to the existing literature by addressing several of the articulated limitations of previous studies. First, we provide evidence on the level of ORDs in IBs in 10 MENA countries. Second, we provide evidence for the first time on the effect of SSB on the level of ORDs in IBs. Third, we offer new evidence on the impact of other bank-level and country-level governance structures on the level of ORDs in IBs. To the best of our knowledge, this is the first cross-country analysis of ORDs, SSB, and other governance structures in IBs that cover both the pre- and post-2007/08 financial crisis periods to-date. Finally, this paper examines the factors that drive ORDs from a multi-theoretical perspective. Given the different incentives for IBs in engaging in ORDs, the current study is different from prior literature by its ex-ante investigation of ORDs from multiple theoretical perspectives, consisting of agency, signalling, legitimacy, and resource dependence theories, as providing the possible basis for understanding and clarifying ORDs in IBs operating in MENA countries.

The rest of the paper is structured as follows. The next section provides a brief overview of operational risk disclosures in MENA IBs. The following section presents the literature review and hypotheses development. The remaining sections outline the research design, report empirical analyses and provide a conclusion.

\section{Operational Risk Disclosures in MENA Islamic Banks}

MENA countries share similar political and socio-economic characteristics, including, but not limited to concentration of ownership, a growing reputation for Islamic banking and finance, weak governance structures, and poor disclosure practices, as shown in Table 1 (Alshbili et al., 
2019; Distinguin et al., 2010; Haniffa \& Hudaib, 2007). Similarly, the Islamic banking and finance sector has witnessed significant growth in the past three decades, especially in the MENA region. According to the S\&P (2016) and Global Islamic Finance Report (2017) relating to IBs, the Islamic banking and finance industry is worth about US\$2.293 trillion at the end of December 2016, representing an annual growth rate of about $10 \%$. Further, IBs control over $51.2 \%, 45.2 \%$ and $29.3 \%$ of the market share in Saudi Arabia, Kuwait, and Bahrain, respectively, as well as penetrating new markets in Africa, Asia and Europe. For example, it has been predicted that IBs will be able to raise about US\$6.7 trillion by 2020 (Ernst \& Young, 2016; S\&P, 2016).

Insert Table 1 about here

Notwithstanding this phenomenal growth, IBs are dominated by risk. A major reason for the high levels of risk consciousness in IBs is that they need to operate in a Sharia-compliant manner often with the approval of a SSB in every aspect of their operations in addition to the traditional risks that they bear as conventional commercial banks. It should be noted that operating in a Sharia-compliant manner, includes, but not limited to the prohibition of interest (' $R I B A$ ') and speculative activities, and restriction to Islamically acceptable deals and profitsharing models (Mollah \& Zaman, 2015), among others. Therefore, SSBs can serve as an important CG mechanism, which can offer legitimacy and credibility to the operations of IBs (Haniffa \& Hudaib, 2007).

Operational risks in IBs have also become more complex due to the growing financial and technological complexity, large-scale acquisitions and mergers, new business activities, globalisation, and regulations, such as the Basel Accords (BCBS, 2003). With specific reference to the Basel Accords and unlike Basel I, Basel II requires banks to measure, allocate and disclose operational risks (BCBS, 2006). In this case, Basel II defines operational risks, as 
"the risk of loss resulting from inadequate or failed internal processes, people and systems or from external events" (BCBS, 2006, p.144). More importantly, the third Pillar (market discipline) of Basel II sets disclosure requirements to evaluate key operational risk information regarding the scope of application, risk exposures, risk appetite framework, risk assessment processes, and operational risk capital adequacy (Barakat \& Hussainey, 2013; Iren et al., 2014).

It is worth noting that the Basel II Accord proposed qualitative and quantitative operational risks disclosures regarding strategies, processes, structures and nature of the operational risks used by banks, in addition to operational risk methods that can be used to calculate the minimum capital adequacy requirements. Principally, the Basel II Accord required a qualitative operational risk disclosure that contains (i) operational risk measurement approach, (ii) operational risk management strategies and processes, (iii) operational risk management functional structure and organisation, and (iv) scope and nature of the operational risk reporting system (BCBS, 2006, 2014). The Basel II Accord also expected a quantitative operational risk disclosure that contains operational risk exposure, and the amount of regulatory capital for operational risk (Pillar 1 capital) (BCBS, 2006). Along with the Basel II requirement, similar risk disclosure issues have been addressed by IFRSs 7 and 9, in addition to IASs 32 and 39 (Bischof, 2009). For instance, IFRS 7 requires qualitative and quantitative disclosures relating to risks arising from financial instruments (Bischof, 2009). However, there are no formal granularity within operational risks reporting requirements that are currently in existence (BCBS, 2016). It should also be noted that Basel II Accord is not compulsory for all banks in the MENA region, as shown in Table 2. However, banks in many countries, such as Saudi Arabia, are required to fully comply with Basel II and III (BCBS, 2015a).

Currently, many Islamic banks are reconsidering their operational risks and their governance practices (BCBS, 2014; Izhar \& Asutay, 2010; Young, 2015). Thus, we analyse operational 
risk disclosure drivers because IBs had a substantial degree of freedom regarding operational risk disclosure, as discussed above.

\section{Insert Table 2 about here}

Furthermore, Islamic banks in MENA face a unique challenge in managing their risks, due to the continual political turbulence, distinctive asset and liability structures, and Islamic compliance, which conventional banks are not exposed to (Abedifar et al., 2013; Mokni et al., 2014; Mollah \& Zaman, 2015). Additionally, the need to comply with Islamic governance rules and regulations poses stronger operational risk management challenges compared to their conventional counterparts (Abedifar et al., 2013; Izhar \& Asutay, 2010; Mokni et al., 2014).

Thus and due to the apparent special nature of IBs, Sharia risk arguably emerges as the main operational risk, particularly if IBs were to operate in a manner that is non-compliant with Sharia law and, therefore, an inherent theoretical expectation arises that IBs might be willing to voluntarily disclose more operational risk information relating to their Sharia compliance activities compared to their conventional counterparts (Safieddine, 2009). That is, the religious features of Islamic banks create additional operational risks in terms of Sharia non-compliance risk (Abedifar et al., 2013; Izhar \& Asutay, 2010; Van Greuning \& Iqbal, 2007). Thus, the Islamic Financial Services Board (IFSB) defines operational risks in Islamic banks as, "the risk of loss resulting from inadequate or failed internal processes, people, and system, or from external events, which includes, but is not limited to, legal risk and Sharia non-compliance risk" (IFSB, 2005, p. 26). Sharia non-compliance risk is a distinctive and significant aspect of Islamic banks rising from Islamic bank failure to comply with Sharia rules and principles governed by the relevant Sharia body in the jurisdiction, which can have a negative effect on bank income (IFSB, 2005; Izhar \& Asutay, 2010). In summary, it could be argued that Islamic banks face three main operational risks, (i) Sharia non-compliance risk that is a unique risk, 
(ii) general risks which result from regular banking activities, and (iii) legal risks that are generally similar to, but are not necessarily limited to, those exposed to by their conventional counterparts (IFSB, 2005; Izhar \& Asutay, 2010; Van Greuning \& Iqbal, 2007). Thus, we conjecture that the antecedents of ORDs in IBs can be expected to differ from those of conventional counterparts. As such, studying the ORDs in IBs, where empirical findings are rare, can contribute to current knowledge and understanding of the motives and determinants of ORDs' practices.

\section{Literature Review and Hypotheses Development}

Previous studies (e.g., Abdallah et al., 2015; Barakat \& Hussainey, 2013; Helbok \& Wagner, 2006) have identified a number of factors that can drive general voluntary disclosures, including ORDs. Therefore and distinguishing the current study from most previous studies, we investigate how SSBs influence ORDs. We also examine how bank-level CG mechanisms in the form of block shareholding, board size, and NEDs, as well as country-level governance mechanisms drive ORDs in MENA IBs.

\subsection{Islamic Governance (SSB) and ORDs}

Islamic governance in the form of the SSB is an important internal CG mechanism assuring Sharia compliance, which is rooted in Sharia principles and rules. Theoretically, agency theory suggests that effective SSB can mitigate agency conflicts and information asymmetry between insiders (management) and shareholders by providing fruitful and independent supervision regarding Sharia-compliant products and operations (Safieddine, 2009). Second, signalling and legitimacy theories predict that independent SSB with wide expertise and knowledge can help legitimise IBs' operations by securing the approval of the broader society through its encouragement of mangers of IBs to engage in increased ORDs (Connelly et al., 2011). Finally, resource dependence theory predicts that SSB can help in granting IBs access to essential 
resources by enhancing ORDs by managers of IBs (Ntim et al., 2013; Pfeffer \& Salancik, 2003).

Empirically, Farook et al. (2011), Haniffa and Hudaib (2007) and Rahman and Bukair (2013) examine the drivers of IBs' corporate social responsibility (CSR) disclosures, and find that the SSB characteristics (proxies by the SSB existence, SSB members, SSB members' doctoral education, cross-memberships, and respectable scholars as members of SSBs) positively impact the level of CSR disclosure. Mallin et al. (2014) also examine the relationship between SSB and CSR disclosure using a sample of 90 Islamic banks from 2010 to 2011 across 13 countries. They find a positive relationship between SSB size and CSR disclosure, which highlights the important role of the SSB in supporting IBs' social disclosure. Abdullah et al. (2013) examine the impact of SSB on CG disclosure and quality of financial reporting, respectively. They find a positive impact of SSB on corporate governance disclosure and financial reporting quality, respectively. Finally, using a sample of 75 Saudi listed firms from 2004 to 2010, AI-Bassam and Ntim (2016) report that Islamic values incorporating SSB have a positive impact on the level of voluntary CG disclosures. Noticeably, and to the best of our knowledge, there is one study that has examined the impact of SSB on ORDs. Neifar and Jarboui (2018) found that the presence of a SSB has a negative impact on operational risk disclosure, which contradict the above studies. We, therefore, seek to contribute to the existing literature by examining the effect of SSB on ORDs. Specifically, we innovatively employ a number of SSB characteristics (i.e. SSB existence, SSB members, and SSB meetings), which reflect SSB quality based on IFSB guidelines (IFSB, 2005) and past studies, as shown in Appendix B. Therefore, the study hypothesises that:

$\mathrm{H}_{1}$ : There is a positive link between SSB characteristics (i.e., SSB existence, SSB members, and SSB meetings) and the level of ORDs in MENA Islamic banks. 


\subsection{Ownership Structure, Board Mechanisms, and ORDs}

Ownership structure has been suggested as a main driver of ORDs. Theoretically, ownership concentration in terms of block ownership can affect ORDs in two ways. On the one hand, agency theory predicts that block shareholders face less agency conflict, as they can obtain direct access to vital information, and so we can expect fewer ORDs in IBs with high levels of block shareholding. In contrast, signalling, legitimacy, and resource dependence theories expect that block shareholders may enhance ORDs to send signals to the external environment about a bank's prudent risk management practices as a way of securing vital resources, as well as legitimising its operations, and thereby gaining public trust.

Empirically, Zouari and Taktak (2014) document that more than 70\% of IBs ownership is controlled by the highest 5 owners. A number of previous research in developing countries support agency they and provide an evidence that there is a negative relationship between block ownership and the level of voluntary disclosure (Haniffa and Cooke, 2002; Htay, 2012). In IBs context, Grassa and Chakroun (2016) document that voluntary disclosure (i.e., corporate governance disclosure) is negatively related to block ownership in GCC banks. Also, Albassam and Ntim (2017), Mokhtar and Mellett (2013) and Ntim et al. (2013) find a negative relationship between block ownership and the level of risk disclosure in large listed nonfinancial firms. By contrast, O’Sullivan et al. (2008) find no association between block ownership and level of risk disclosure in large listed non-financial firms. Finally, the findings of other past studies such as Grassa et al. (2018) and Neifar and Jarboui (2018) found that ownership concentration has a positive impact on Islamic banks (IBs) product and services disclosure, and operational risk disclosure in a sample of IBs, respectively. We follow the main literature that found a negative relation between block ownership and level of risk disclosure and therefore, our study sets the following hypothesis, which states that: 
$\mathrm{H}_{2}:$ There is a significant negative link between block ownership and the level of ORDs in MENA Islamic banks.

Board structure provides another significant dimension which, alongside bank ownership, may have a profound effect on ORDs. Specifically, BCBS (2003, 2014), and IFSB (2005) demonstrate the importance of board of directors in reviewing and approving the operational risk management objectives, policies, strategies and processes that are consistent with the IBs' risk culture and risk tolerance, and with sound principles of operational risks. Agency theory predicts that larger and independent boards with great in-depth knowledge can increase managerial monitoring and may reduce information asymmetry by enhancing ORDs. Jensen and Meckling (1976) find that bigger boards improve the monitoring role of directors, with more qualified and experienced members. Thus, a strong board of directors can increase a firm's value by enhancing ORDs. Signalling, legitimacy, and resource dependence theories expect that larger and independent boards may enhance ORDs to send a signal to the external environment about a bank's performance, and thereby securing vital resources as well as legitimising their operations by gaining public trust. By contrast, other studies suggest that bigger boards may lead to slow decision making, more conflict and time-wasting (e.g., Fama \& Jensen, 1985; Jensen, 1993), which may affect ORDs negatively.

Empirically, Alnabsha et al. (2018), Mokhtar and Mellett (2013) and Ntim et al. (2013; 2016) find a significant positive association between board size and the level of disclosure. In contrast, Cheng and Courtenay (2006) find an insignificant association between board size and the level of disclosure. Finally, Domínguez and Gámez (2014) show a negative relation between board size and risk disclosure using a sample from the Spanish context. However, all these studies focus on non-financial firms, thereby limiting current understanding of this relationship in banks in general, but IBs in particular. Thus, we hypothesise: 
H3: $_{3}$ There is a significant positive link between board size and the level of ORDs in MENA Islamic banks.

Board independence has been suggested as a key determinant of ORDs. Specifically, a number of corporate governance codes (e.g., EIoD, 2016; OCED, 2015) and sound principles of corporate governance and operational risks (BCBS, 2011, 2014) demonstrate the importance of board independence. Agency theory predicts that independent boards with great experience and knowledge can enhance monitoring and reduce information asymmetry through their ability to encourage managers to engage in increased ORDs. Barakat and Hussainey (2013) find that independent boards have a positive effect on ORDs. Signalling, legitimacy, and resource dependence theories suggest that independent boards may enhance ORDs by sending a signal to the external environment about bank performance. ORDs may also help to secure vital resources as well as legitimise IBs' operations and gain public trust.

Empirically, a number of studies suggest that board independence (i.e., NEDs) may improve the level of ORDs (e.g., Barakat \& Hussainey, 2013; Mallin et al., 2014). In contrast, a few studies suggest a non-significant relationship between board independence and ORDs (Barakat \& Hussainey, 2013), but none of these studies has examined such a relationship in banks or IBs. This provides a unique opportunity to contribute to the extant literature and, thus, we hypothesise that:

$H_{4}:$ There is a significant positive link between NEDs and the level of ORDs in MENA Islamic banks.

\subsection{Country-level Governance and ORDs}

Recently, many MENA countries have pursued new regulatory reforms in order to enhance investor protection and increase corporate transparency. Specifically many countries, such as 
Saudi Arabia, have adopted Basel Accords, International Financial Reporting Standards (IFRS), and corporate governance codes. However, the impact of country governance quality on banks' operational disclosure levels remains largely unexplored. Agency theory, on the one hand, predicts that countries with good governance institutions may mitigate agency conflicts through enhanced minority rights and increased information transparency via high ORDs. In other words, strong country governance arrangements may encourage managers to provide more ORDs because they may restrict managers' ability to behave opportunistically, and thus help alleviate the incentives of those managers to provide less ORDs to the banks' stakeholders (Barakat \& Hussainey, 2013; Ernstberger \& Grüning, 2013). On the other hand, it can be argued that country-level governance practices may serve a monitoring role in weak corporate governance environments compared to the case in their strong counterparts. Specifically, weak country governance environments often lead to increased agency costs; and thereby, banks may need to improve their firm-level governance in the form of increased ORDs; and vice-versa. Similarly, IBs might choose to increase their ORDs, particularly in countries that suffer from political instability, in order to signal their better performance so as to secure vital resources from the external environment.

Empirically, a few studies (Barakat \& Hussainey, 2013; Elamer et al., 2018; Ernstberger \& Grüning, 2013; Tunyi \& Ntim, 2016) have examined the role of country-level governance in promoting ORDs. For example, Barakat and Hussainey (2013) find a positive but insignificant relationship between country-level governance in terms of rule of law and ORDs, whilst Tunyi and Ntim (2016) find that national governance quality has a positive impact on mergers and acquisitions in Africa. On the other hand, using a sample from 16 European countries, Ernstberger and Grüning (2013) find that the positive effect of corporate governance on disclosure is higher in countries with good national governance quality than in those with poor national governance quality. This leads us to hypothesise that: 
$H_{5}$ : There is a statistically significant relation between country-level governance and the level of ORDs in MENA Islamic banks.

\section{Research Design}

\subsection{Sample and Data Considerations}

Following recent cross-country studies (Ntim, 2016; Tunyi \& Ntim, 2016; Elamer et al., 2017), our sample comprises all listed IBs from 10 countries in the Arab MENA region - Bahrain, Egypt, Jordan, Kuwait, Lebanon, Oman, Qatar, Saudi Arabia, Syria, and the UAE - based on the Bankscope Database as summarised in Table 3, with full data from 2006 to 2013. Hence, our final sample covers 63 banks over eight years, leading to a total of 412 bank-year observations for our regression analysis.

Insert Table 3 about here

This study uses data from three distinct sources. First, ORDs, SSB characteristics, and CG variables were gathered from annual reports, which were downloaded from banks' websites and the Perfect Information Database. Second, financial data were extracted from the Bankscope Database. Third, country-level macro statistics and WGI were downloaded from the World Bank database.

\subsection{Definition of Variables and Model Specification}

The study's variables are classified into five main types and Table 4 contains a full description of all the variables employed. First, and to examine $\boldsymbol{H}_{1}$ to $\boldsymbol{H}_{5}$, the main dependent variable is the ORDs' scores, which measures the level of ORDs.

Insert Table 4 about here 
We collect individual operational risk items from the Basel II guidelines and the main operational risk disclosure items that are employed in closely related studies (e.g., Barakat \& Hussainey, 2013; Helbok \& Wagner, 2006; Ntim et al., 2013) to form our ORDs' index. Hence, the ORDs' index contains 22 provisions as shown in Appendix $\mathrm{A}^{1}$.

Second, and to test $\boldsymbol{H}_{1}$ to $\boldsymbol{H}_{5}$, we collect data on Sharia supervisory boards' (SSBs') characteristics. We rely on several proxies to capture SSB quality based on closely related studies (e.g., Abdullah et al., 2015; Farook et al., 2011; IFSB, 2005; Mallin et al., 2014; Rahman \& Bukair, 2013). Specifically, SSB characteristics include: (i) SSB Existence (SSBE), (ii) SSB Members (SSBM), and (iii) SSB Meetings (SSBT).

Insert Table 5 about here

Third, to measure governance structures, the three CG mechanisms (block ownership (BLCK), board size $(B O S Z)$, board independence $(N E D s))$ are used. Fourth, the measure of country-level governance $(C L G)$ employed in our regression is a composite measure that includes all dimensions of worldwide governance indicators. Previous research shows a high correlation between $C L G$ dimensions (e.g., Kaufmann et al., 2011; Tunyi \& Ntim, 2016). Hence, we employed principal component analysis (PCA) to create a composite measure of CLG and the results are shown in Table 5. Table 5 suggests that sampling adequacy for each factor and for the whole model is appropriate for statistical analysis. The Kaiser-Meyer-Olkin (KMO) that measures sampling adequacy is above 0.60 (Tunyi \& Ntim, 2016).

\footnotetext{
${ }^{1}$ We use two dependent variables: unweighted operational risk disclosures and weighted operational risk disclosure. For the un-weighted operational risk disclosures index, each of the 22 items has a score ranging from 0 to 1 (i.e., 0 - operational risk item is not disclosed by a bank; 1- operational risk item is disclosed by a bank). This un-weighted scoring procedure can result in a total potential score of 22 ; scaled to a value between $0 \%$ and $100 \%$. For the weighted operational risk disclosure index, each of the 22 items has a score ranging from 0 to 2 (i.e., 0 - operational risk item not disclosed by a bank; 1 - operational risk item disclosed by a bank and contains past, future, good, bad and/or qualitative information; 2- operational risk item disclosed by a bank and contains past, future, good, bad, qualitative and/or quantitative information). This weighted scoring procedure can result in a total potential score of 44 ; scaled to a value between $0 \%$ and $100 \%$. These ORD items and the scoring procedure are contained in Appendix A.
} 
Finally, we employ a wide range of bank characteristics as control variables. These include bank size (SIZE), performance (ROA), liquidity (LIQ), income diversity (INCD), and operations efficiency $(C O S T)$, as well as macro variables like GCC countries $(G C C)$, financial crisis $(C R S)$, inflation (INFL), GDP per capita $(G D P C)$, and dummies for each of the fiscal years $(Y D)$. We do not develop direct theoretical associations between these variables and ORDs for brevity, but a considerable number of prior studies have found that these can affect ORDs (Abdallah et al., 2015; Barakat \& Hussainey, 2013; Farook et al., 2011; Ford et al., 2009; Helbok \& Wagner, 2006).

We use the panel data fixed effects regression technique, which considers all conceivable variations in $O R D s$ due to variations in $\mathrm{SSB}, \mathrm{CG}$, and country-level governance over the eightyear period (Ntim et al., 2013). Additionally, we use the fixed effects model rather than the random effects model because Hausman's specification test rejected random effects in favour of fixed effects. Therefore, the model to be estimated is specified as,

$$
O R D_{i t}=\alpha_{0}+\beta_{i} S S B_{i t}^{3}+\beta_{i} \sum_{i=1}^{3} C G_{i t}+\beta_{i} C L G_{i t}+\sum_{i=1}^{9} \beta_{i} C O N T R O L S_{i t}+\delta_{i t}+\varepsilon_{i t}
$$

where, $O R D s$ is proxy for operational risk disclosures, $S S B$ denotes vector of SSB variables which contains SSB existence (SSBE), SSB members (SSBM), and SSB meetings (SSBT). CG refers to $B L C K, B O S Z$, and NEDs. Country-level governance refers to $C L G$, and CONTROLS refers to the control variables, including SIZE, ROA, LIQ, INCD, COST, CRS, GCC, INFL, $G D P C . \delta_{i t}$ denotes bank-year specific fixed effect and $\varepsilon$ is the error term.

We present the empirical analyses, including the descriptive statistics, and bivariate and multivariate regressions in the following sections. 


\section{Findings and Discussion}

\subsection{Descriptive and Correlation Analyses}

Table 6 summarises descriptive statistics of all the variables contained in our analysis, and reports a number of remarkable findings. First, it reports that the mean of total operational risk disclosures is $11.82(53.73 \%)$ ORDs score. Second, it also reports that there is a large degree of variability in the $O R D s$ across different IBs. For example, ORDs range from a minimum of $0(0.00 \%)$ to a maximum of $22(100 \%)$ with a standard deviation of 4.75 . Our finding is consistent with the prior empirical literature findings (Haniffa \& Hudaib, 2007; Mokhtar \& Mellett , 2013; Ntim et al., 2013; Rahman \& Bukair, 2013). The large degree of variation in ORDs among IBs may be due to the fact that the ORDs' index items are voluntary, as well as the fact that the variations may reflect differences in country-level governance and institutions' quality.

Insert Table 6 about here

Second, Table 6 reports that $31 \%$ of Islamic banks do not have SSB. SSB members (SSBM) are between zero and seven with a mean of three members. From the above-mentioned SSB statistics, it could be argued that there is a large difference between Islamic banks in the MENA region regarding SSB structure and meetings frequency. It also offers support for prior findings (AI-Bassam \& Ntim, 2016; Farook et al., 2011; Rahman \& Bukair, 2013), which indicate that SSB structures are primarily poor.

BOSZ is between five and 15 with an average of nine board members, which is in line with OCED and MENA CG codes' recommended best practice, and consistent with previous studies (Mollah \& Zaman, 2015; Ntim et al., 2013). NEDs is between $0.00 \%$ and $100 \%$ with an average of $88 \%$, which is considered as an indicator for board independence and in line with OCED CG best practice, but interestingly, there are banks that do not have any NEDs, which may 
result from increased block shareholding. The results are also similar to the prior literature (Barakat \& Hussainey, 2013; Mollah \& Zaman, 2015). Also, the mean of block shareholding $(B L C K)$ is $53.32 \%$, which is higher compared to the OCED's CG best practice recommendation); the findings are, however, similar to the results of Ntim et al. (2013).

Table 6 illustrates that country-level governance quality $(C L G)$ in the MENA region is low with a mean of 0.33 , and ranges from -0.95 to 0.80 . In addition, IBs look financially healthy. For example, the mean liquidity ratio is 53.41 and most of the IBs in our sample are making a profit with a mean profitability ratio of $9 \%$. The values of SIZE, INCD, COST, GCC, INFL and $G D P C$ suggest wide variability in our sample, thus reducing any potential of sample selection bias.

Insert Table 7 about here

Table 7 reports the Pearson's and Spearman's correlation matrices to test multicollinearities. We report both the Pearson's parametric and Spearman's non-parametric coefficients. Noticeably, the significance and direction of both coefficients are mostly alike, and this shows that no severe non-normality problems exist. The correlations between the variables are also generally lower than 0.60 , implying that there are no serious multicollinearity problems. In addition, Table 7 shows statistically significant connections between $O R D s$ and the independent variables. For example, and as expected, SSBE, SSBM, SSBT, BLCK, NEDs, CLG, SIZE, LIQ, and GCC are statistically significant and positively associated with $O R D s$, whilst $B O S Z, R O A, I N C D$ and INFL are statistically significant and negatively related to $O R D s$. Together, the results offers support for past evidence (e.g., AI-Bassam \& Ntim, 2016; Barakat \& Hussainey, 2013; Farook et al., 2011; Mollah \& Zaman, 2015). 


\subsection{Regression Analyses}

Table 8 reports the regression analysis results of the impact of SSBs and governance structures on ORDs. Generally, the findings show that the SSB, CG and country-level governance mechanisms are important in explaining differences in ORDs. First, the coefficients of the SSB proxies (i.e., $S S B E, S S B M$, and $S S B T$ ) in Models 1 to 3 of Table 8 are positive and statistically significant, implying that IBs with high SSB quality are more likely to make increased operational risk disclosures. This implies that SSBs may impose pressure on managers to engage in increased ORDs. The positive connection between $S S B$ and $O R D s$ is in line with theoretical suggestions that $S S B$ mitigates agency conflicts via serving as additional CG layer for monitoring managers, thus resulting in increased disclosures. Our findings similarly offer practical support for $\boldsymbol{H}_{\boldsymbol{1}}$ and previous findings (Farook et al., 2011), which suggest that SSB has a positive impact on $O R D s$.

Second, the coefficient of $B L C K$ in Models 1 to 3 of Table 8 is positive. Hence, we reject $\boldsymbol{H}_{2}$. This result is consistent with Neifar and Jarboui (2018). This result is inconsistent with the findings of Mokhtar and Mellett (2013), and Ntim et al. (2013), which suggest that block shareholding is negatively related to risk disclosures. Similarly, Models 1 to 3 of Table 8 suggest a negative relationship between board size (BOSZ) and ORDs; although this relationship is not statistically significant. The negative association between BOSZ and ORDs is in line with the findings of Cheng and Courtenay (2006), Arcay and Vazquez (2005) and Prado-Lorenzo and Garcia-Sanchez (2010). Thus, we reject $\boldsymbol{H}_{3}$. Also, Table 8 reports a positive and statistically significant association between NEDs and ORDs. This result provides further empirical support for agency, signalling, legitimacy, and resource dependence theories and previous studies (Neifar \& Jarboui, 2018). This implies that the current result seems to reflect an additional demand for ORDs by independent boards. Consequently, IBs with large independent boards appear to commit to high levels of ORDs in order to mitigate agency costs, 
and thereby facilitate access to vital resources such as Sukuk, and thus legitimise their operations. Hence, we accept $\boldsymbol{H}_{\boldsymbol{4}}$.

Insert Table 8 about here

Third, our results suggest that variances in the ORDs can largely be explained by the countrylevel governance $(C L G)$. The coefficient of $C L G$ is significant statistically and positively linked to $O R D s$ in Models 1 to 3 of Table 8, and it also provides empirical support for agency, signalling, legitimacy and resource dependence theories. This result implies that a better governed environment affords better protection for investors. Accordingly, IBs commit to high levels of information transparency via increased ORDs in better governed countries compared to the case in other countries. Models 1 to 3 of Table 8 report that IBs choose to increase ORDs in countries that have high country-level governance quality to signal their performance and secure vital resources from the external environment. Hence, we accept $\boldsymbol{H}_{5}$. This result provides an exciting opportunity to advance our knowledge of country-level governance $(C L G)$ and its influence on $O R D s$.

Fourth, Table 8 reports a positive association between SIZE, LIQ and ORDs, while it shows an insignificant relation between ROA, INCD, COST, INFL, GDPC and ORDs. These results in general support prior studies’ findings (Barakat \& Hussainey, 2013; Ntim et al., 2013).

\subsection{Robustness Test}

We carry out a number of robustness tests in order to address any potential endogeneity problems and sensitivities that may be present in our regression models. First, we test the robustness of our ORDs index results by re-regressing equation (1) using weighted ORDs, as alternative operational risk disclosure index. The results stated in Models 4 to 6 of Table 8 are mostly the same with those results reported in Models 1 to 3 of Table 8 with a slight difference 
in the significance of the coefficients. Therefore, these findings indicate that our results are robust whether the ORDs' index is un-weighted or weighted.

Insert Table 9 about here

Second, to address potential endogeneity problems that may be due to unobserved predictor factors' bias (Larcker \& Rusticus, 2010; Ntim \& Soobaroyen, 2013), we use two-stage least squares (EC2SLS) for the random effect panel data model. In the first stage, based on extensive theoretical and empirical research (Larcker \& Rusticus, 2010; Ntim \& Soobaroyen, 2013), we conjecture that CG variables (i.e., block ownership, board size, and board independence) and SSB will be determined by all the control (exogenous) variables specified in equation (1). In the second stage, we employ the predicted values of the CG variables and SSB as an instrument for the CG variables and SSB and re-estimate equation (1) as specified below:

$$
O R D_{i t}=\alpha_{0}+\hat{\beta}_{i} S S B_{i t}^{3}+\hat{\beta}_{i} \sum_{i=1}^{3} C G_{i t}+\beta_{i} C L G_{i t}+\sum_{i=1}^{9} \beta_{i} C O N T R O L S_{i t}+\delta_{i t}+\varepsilon_{i t}
$$

where, everything remains unaffected as identified in equation (2) except that we use instrumental variables for CG variables and SSB variables. The results, reported in Model 1 to 6 of Table 9 are similar to those reported in Models 1 to 6 in Table 8, and thus suggest that our findings do not suffer from any potential endogeneity problems.

Finally, we estimate equation (2) by employing another econometric methodology to address potential endogeneity issues in our model. Islamic banks may consider a need for adjusting their quality of operational risk disclosure in response to the riskiness prevailing in their banking sector, producing an endogeneity issue in our result. Although we have used the 2SLS estimator to allow for endogeneity issues in our estimation, we try to address this potential of 
reversed causality by alternatively using the dynamic system GMM estimator. We follow the approach of prior research (Arellano \& Bover, 1995; Elamer et al., 2017; Wintoki et al., 2012) by using a dynamic panel regression of the form:

$$
O R D_{i t}=\alpha_{1}+k_{1} O R D_{i t-1}+\beta X_{i t}+\gamma Z_{i t}+\delta_{i t}+\varepsilon_{i t}
$$

where $O R D s$ is proxy for operational risk disclosures for bank $i$ during year $t . X_{i t}$ denotes all explanatory variables that include $S S B$ characteristics, BLCK, BOSZ, NEDs and CLG. $Z_{i t}$ refers to SIZE, ROA, LIQ, INCD, COST, CRS, GCC, YD, INFL and GDPC. $\delta_{i t}$ is the unobserved bank-year specific fixed-effects, and $\varepsilon_{i t}$ is the white noise error term. The estimation results on operational risk disclosures, using the two-step system GMM estimator, are reported in Table 10. Overall, we find consistent evidence that Sharia supervisory board and governance structure are key determinants of the operational risk disclosure in most of the regression models. Finally, IBs commit to reporting high levels of information transparency via increased $O R D s$ in $G C C$ countries compared to other countries in the MENA region due to the fact that, in the last decade, GCC countries have embarked on stronger CG reforms (AlHadi et al., 2016; Al-Malkawi et al., 2014; Dalwai et al., 2015; Elamer, 2017; Shehata, 2015), as well as adopting, implementing and enforcing the requirements of IFRS and Basel II and III accords (Al-Hadi et al., 2016; Bitar et al., 2016; Dalwai et al., 2015; Elamer et al., 2017; Haque \& Brown, 2017) compared to their non-GCC counterparts. Future studies may develop nonparametric techniques such as Neural Networks (Abdou et al., 2019) or/and examine the impact SSB on CSR, environmental performance, carbon taxes and Integrated Reporting (IR) (e.g., Adhikariparajul et al., 2019; Elmagrhi et al., 2019; McLaughlin et al., 2019).

\section{Summary and Conclusion}

The weaknesses of operational risk management and disclosure practices, as well as corporate governance (CG) structures in the wake of the financial crisis have reignited the debate relating 
to the importance of managing operational risk management and disclosure practices within the banking sector worldwide. Therefore, this paper has examined the impact of Sharia supervisory boards, bank-level governance mechanisms, and country-level governance structures on operational risk disclosures, using a sample of 63 Islamic banks from 10 (i.e., Bahrain, Egypt, Jordan, Kuwait, Lebanon, Oman, Qatar, Saudi Arabia, Syria, and the UAE) countries in the MENA region for fiscal years 2006-2013. Our findings are threefold. First, we find that the level of operational risk disclosures (ORDs) in the Gulf Cooperation Council countries is, on average, higher than those of other MENA countries. Second, we find that SSB, block ownership, board independence, and a country-level governance quality are statistically significant and positively associated with ORDs. Finally, and by contrast, our findings indicate that the impact of board size is negative and statistically significant. This paper, therefore, extends, as well as makes a number of new contributions to the existing literature.

First, while operational risk disclosures worldwide consist of a variety of specific disclosures, including regulatory capital for operational risk, operational risk management strategies and processes, and operational risk transfer/mitigation/hedging techniques, in our setting where Islamic banks in MENA face a unique challenge in managing their risk due to the continual political turbulence, distinctive asset and liability structures and Islamic compliance compared to conventional commercial banks allows us to emphasise the salient aspect of IBs governance structure (i.e., the Sharia supervisory board). Second, this study offers comprehensive evidence about the role of bank-level corporate governance mechanisms in determining operational risk disclosure levels. Third, we use a unique dataset from Islamic banks in 10 MENA countries, where banks' annual reports are expected to disclose more information related to operational risks. A cross-country basis provides the ability to mutually cogitate the role of the bank-level governance and that of country-level governance. We, hence, add to the new and emerging nascent research regarding the relevance of country-level governance in shaping operational 
risk disclosure decisions, which in turn, can decrease information asymmetry. Thus, our findings have significant implications for regulators, policymakers, shareholders, and borrowers and savers, particularly those operating in developing countries, where Islamic banking have experienced substantial growth in the past decades.

The findings support the current regulatory corporate governance reforms that place emphasis on the importance of sound risk management along with good corporate governance, disclosure and transparency practices in MENA countries. Policymakers and regulators should, therefore, undertake a fundamental review of corporate governance codes within the banking sector in general with special emphasis on the importance of SSB in Islamic banks. The finding of wide differences in the level of ORDs also suggests that some attention needs to be paid by IBs to the level of ORDs. One potential recommendation is to implement and enforce a disclosure framework, which has been issued by the Basel Committee on Banking Supervision, which encourages ORDs by banks.

Although our results are robust, there are some limitations that need to be clearly acknowledged. First, the ORDs' data were manually gathered; this involved a great deal of time, and hence restricted our focus to a MENA sample of IBs and the combined components of ORDs (e.g., Sharia incompliance risk). Future studies may analyse how SSBs and governance structure affect components of ORDs with further expansions (e.g., Sharia noncompliance risk). Second, although the findings obtained by using the unweighted/weighted ORDs' index seem to be principally the same, researchers may improve their investigation by using different ORDs' measures (e.g., pages number/sentences counted). Finally, future research may improve their investigation by examining how other CG mechanisms, such as audit committee, risk committee and other board variables may influence ORDs' practices. 


\section{Appendix A. Operational risk disclosures index items' sources}

\begin{tabular}{|c|c|}
\hline Disclosure item & \\
\hline $\begin{array}{l}\text { (i) Amount of regulatory capital for } \\
\text { operational risk (Pillar } 1 \text { capital). }\end{array}$ & $\begin{array}{l}\text { (Barakat \& Hussainey, 2013; BCBS, 2006, } \\
\text { 2014b, 2015b, 2016; IAS 1.134-135). }\end{array}$ \\
\hline $\begin{array}{l}\text { (ii) Regulatory capital for operational risk } \\
\text { measurement approach. }\end{array}$ & $\begin{array}{l}\text { (Barakat \& Hussainey, 2013; BCBS, 2014, } \\
\text { 2014c, 2016). }\end{array}$ \\
\hline $\begin{array}{l}\text { (iii) Operational risk management strategies } \\
\text { and processes. }\end{array}$ & $\begin{array}{l}\text { (Barakat \& Hussainey, 2013; BCBS, 2014, } \\
\text { 2015b, 2016; IFRS 7.33; Ntim et al., 2013). }\end{array}$ \\
\hline $\begin{array}{l}\text { (iv) The operational risk management } \\
\text { function structure and organisation. }\end{array}$ & $\begin{array}{l}\text { (Barakat \& Hussainey, 2013; BCBS, 2014, } \\
\text { 2015b, 2016; IFRS 7.33; Ntim et al., 2013). }\end{array}$ \\
\hline $\begin{array}{l}\text { (v) Scope and nature of the operational risk } \\
\text { reporting system. }\end{array}$ & $\begin{array}{l}\text { (Barakat \& Hussainey, 2013; BCBS, 2014, } \\
\text { 2015b, 2016; IFRS 7.33; Ntim et al., 2013). }\end{array}$ \\
\hline $\begin{array}{l}\text { risk } \\
\text { n/hedging techniques. }\end{array}$ & $\begin{array}{l}\text { (Barakat \& Hussainey, 2013; BCBS, 2014, } \\
\text { 2015b, 2016; Ntim et al., 2013). }\end{array}$ \\
\hline (vii) Op & $\begin{array}{l}\text { (Barakat \& Hussainey, 2013; Ford et al., } \\
\text { 2009). }\end{array}$ \\
\hline nal audit function/internal control & $\begin{array}{l}\text { (Barakat \& Hussainey, 2013; BCBS, 2014; } \\
\text { Helbok \& Wagner, 2006; Mokni et al., 2014; } \\
\text { Ntim et al., 2013; Van Greuning \& Iqbal, } \\
\text { 2007). }\end{array}$ \\
\hline $\begin{array}{l}\text { (ix) Key risk indicators (KRIs)/early } \\
\text { warning systems (EWSs). }\end{array}$ & $\begin{array}{l}\text { kat \& Hussainey, 2013; BCBS, 2014; } \\
\text { et al., 2009; Mokni et al., 2014; Young, } \\
\text {. }\end{array}$ \\
\hline (x) Self-assessment techniques (SA). & $\begin{array}{l}\text { \& Hussainey, 2013; Ford et al., 2009; } \\
\text { 2015). }\end{array}$ \\
\hline $\begin{array}{l}\text { (xi) Str } \\
\text { analyse }\end{array}$ & $\begin{array}{l}\text { y, 2013; Ford et al., 2009; } \\
\text { Young, 2015). }\end{array}$ \\
\hline $\begin{array}{l}\text { (xii) Operational risk event databases } \\
\text { (internal/external). }\end{array}$ & $\begin{array}{l}\text { (Barakat \& Hussainey, 2013; BCBS, 2014; } \\
\text { Ford et al., 2009; Mokni et al., 2014; Van } \\
\text { Greuning \& Iqbal, 2007; Young, 2015). }\end{array}$ \\
\hline (xiii) Legal risks. & $\begin{array}{l}\text { ainey, 2013; Helbok \& } \\
\text { l Greuning \& Iqbal, 2007). }\end{array}$ \\
\hline $\begin{array}{l}\text { (xiv) Additional information on risk } \\
\text { exposure and management (e.g., cumulative } \\
\text { amounts of historical operational losses } \\
\text { classified by event types and business). }\end{array}$ & $\begin{array}{l}\text { (Barakat \& Hussainey, 2013; Van Greuning \& } \\
\text { Iqbal, 2007). }\end{array}$ \\
\hline (xv) Technology/information technology. & $\begin{array}{l}\text { elbok \& Wagner, 2006; Ntim et al., 2013; } \\
\text { in Greuning \& Iqbal, 2007). }\end{array}$ \\
\hline (xvi) Compliance with Sharia. & $\begin{array}{l}\text { (Ntim et al., 2013; Van Greuning \& Iqbal, } \\
\text { 2007) }\end{array}$ \\
\hline $\begin{array}{l}\text { (xvii) } \\
\text { satisfaction/boycott. }\end{array}$ & $\begin{array}{l}\text { (Ntim et al., 2013; Van Greuning \& Iqbal, } \\
\text { 2007). }\end{array}$ \\
\hline (xviii) Competition/ proprietary/ copyright. & $\begin{array}{l}\text { (Ntim et al., 2013; Van Greuning \& Iqbal, } \\
\text { 2007). }\end{array}$ \\
\hline $\begin{array}{l}\text { (xix) } \text { Personnel } \\
\text { disputes, loss of/1 }\end{array}$ & $\begin{array}{l}\text { (Helbok \& Wagner, 2006; Ntim et al., 2013; } \\
\text { Van Greuning \& Iqbal, 2007) }\end{array}$ \\
\hline
\end{tabular}




\begin{tabular}{|l|l|}
\hline $\begin{array}{l}\text { (xx) Integrity/management and employee } \\
\text { fraud. }\end{array}$ & $\begin{array}{l}\text { (Helbok \& Wagner, 2006; Ntim et al., 2013; } \\
\text { Van Greuning \& Iqbal, 2007). }\end{array}$ \\
\hline (xxi) Business ethics/corruption. & $\begin{array}{l}\text { (Ntim et al., 2013; Van Greuning \& Iqbal, } \\
\text { 2007). }\end{array}$ \\
\hline $\begin{array}{l}\text { (xxii) Disclosures to help users understand } \\
\text { operational risk. }\end{array}$ & $\begin{array}{l}\text { (Barakat \& Hussainey, 2013; BCBS, 2014; } \\
\text { Ford et al., 2009; Van Greuning \& Iqbal, } \\
\text { 2007). }\end{array}$ \\
\hline Total: 22 operational risk disclosure items. \\
\hline Procedure of scoring for un-weighted index. \\
\hline 0: Operational risk item is not disclosed. \\
\hline 1: Operational risk item is disclosed. \\
\hline Procedure of scoring for weighted index \\
\hline 0: Operational risk item is not disclosed. \\
\hline 1: Operational risk item disclosed by bank contains qualitative information. \\
\hline 2: Operational risk item disclosed by bank contains quantitative and qualitative information. \\
\hline
\end{tabular}


Appendix B. Specific examples of ORDs in bank annual reports and use of the coding rules

\begin{tabular}{|c|c|c|c|}
\hline $\begin{array}{l}\text { Bank } \\
\text { name }\end{array}$ & Examples of ORDs & $\begin{array}{l}\text { ORDs } \\
\text { category(ies) }\end{array}$ & Coding \\
\hline $\begin{array}{l}\text { Gulf } \\
\text { Finance } \\
\text { House } \\
\text { (Bahrain) }\end{array}$ & $\begin{array}{l}\text { "The Group is committed to avoid recognising any } \\
\text { income generated from non-Islamic sources. } \\
\text { Accordingly, all non-Islamic income is credited to } \\
\text { a charity account where the Group uses these } \\
\text { funds for charitable means. Movements in non- } \\
\text { Islamic funds are shown in the statement of } \\
\text { sources and uses of charity funds. } \\
\text { The Group receives interest from deposits placed } \\
\text { with the Central Bank of Bahrain and other } \\
\text { incidental or required deposits. These earnings are } \\
\text { utilised exclusively for charitable purposes and } \\
\text { amounts to US\$ } 4 \text { thousand (2012: US\$ } 1 \\
\text { thousand)" (Gulf Finance House, 2013, p.84). }\end{array}$ & $\begin{array}{l}\text { Compliance } \\
\text { with Sharia }\end{array}$ & $\begin{array}{l}2: \\
\text { Operational } \\
\text { risk item } \\
\text { disclosed by } \\
\text { bank } \\
\text { contains } \\
\text { qualitative } \\
\text { information. }\end{array}$ \\
\hline $\begin{array}{l}\text { Al } \\
\text { Baraka } \\
\text { Bank } \\
\text { Egypt } \\
\text { (Egypt) }\end{array}$ & $\begin{array}{l}\text { "Our Bank belongs to Al Baraka Banking Group, } \\
\text { (the Bank's Principal Investor), as being a Unit of } \\
\text { the Group which stands as one of the leading } \\
\text { Banking Entities in the World, abiding by the } \\
\text { application of the provisions and principles of the } \\
\text { Islamic Shariá in all of its transactions. } \\
\text { This is further evidenced by the Organizational } \\
\text { Structure of the Bank, which embodies a Shariá } \\
\text { Supervisory Board, directly linked to the Bank's } \\
\text { Board of Directors, and consists of three eminent } \\
\text { Scholars specialized in Islamic Shariá and the } \\
\text { Islamic financial transactions, and recognized and } \\
\text { acknowledged for their sound Religious opinions } \\
\text { (Fatwa) and deeply versed in the Jurisprudence of } \\
\text { transactions. The Shariá Supervisory Board } \\
\text { undertake the study and scrutiny of the Contracts } \\
\text { and the Practical Agreements Forms, the } \\
\text { Procedural and Technical Manuals together with } \\
\text { the [Standard] Forms used in the Bank [daily] } \\
\text { activities, in addition to any innovated products, } \\
\text { as concerning the Shariá point of view. This Board } \\
\text { issues Decisions, Recommendations, Religions } \\
\text { opinions (fatwa) in their final form; its Decisions } \\
\text { are binding" (Al Baraka Bank Egypt, 2012, p.29). }\end{array}$ & $\begin{array}{l}\text { Compliance } \\
\text { with Sharia }\end{array}$ & $\begin{array}{l}\text { 1: } \\
\text { Operational } \\
\text { risk item } \\
\text { disclosed by } \\
\text { bank } \\
\text { contains } \\
\text { qualitative } \\
\text { information. }\end{array}$ \\
\hline $\begin{array}{l}\text { Bank } \\
\text { Muscat } \\
\text { SAOG } \\
\text { (Oman) }\end{array}$ & $\begin{array}{l}\text { "This operational risk appetite supports effective } \\
\text { decision making and is central to embedding risk } \\
\text { management in business decisions and reporting. } \\
\text { Business units have the primary responsibility for } \\
\text { identifying, measuring and managing the } \\
\text { operational risks that are inherent in their } \\
\text { respective operations. Operational risk is }\end{array}$ & $\begin{array}{l}\text { The } \\
\text { operational } \\
\text { risk } \\
\text { management } \\
\text { function, } \\
\text { structure and } \\
\text { organisation }\end{array}$ & $\begin{array}{l}1: \\
\text { Operational } \\
\text { risk item } \\
\text { disclosed by } \\
\text { bank } \\
\text { contains }\end{array}$ \\
\hline
\end{tabular}




\begin{tabular}{|c|c|c|c|}
\hline & $\begin{array}{l}\text { controlled through a series of strong internal } \\
\text { controls and audits, well-defined segregation of } \\
\text { duties and reporting lines, detailed operational } \\
\text { manuals and standards. The Operational Risk Unit } \\
\text { oversees the range of operational risk across the } \\
\text { Group in accordance with the Operational Risk } \\
\text { Management Framework. Internal Audit } \\
\text { independently reviews effectiveness of the } \\
\text { Group's internal control and its ability to } \\
\text { minimize the impact of operational risks" (Bank } \\
\text { Muscat SAOG, 2011,p.169). }\end{array}$ & & $\begin{array}{l}\text { qualitative } \\
\text { information. }\end{array}$ \\
\hline $\begin{array}{l}\text { Qatar } \\
\text { Islamic } \\
\text { Bank } \\
\text { (Qatar) }\end{array}$ & $\begin{array}{l}\text { "Information Technology } \text { Process improvements } \\
\text { to reduce the End of Day IT operations and } \\
\text { thereby extend the availability hours for } \\
\text { customers using online channels. } \\
\text { - Implemented COBIT processes and introduced } \\
\text { various controls. } \\
\text { - Renegotiated SLAs and various vendor } \\
\text { contracts, significantly reducing OPEX costs. } \\
\text { - Rationalising software licenses by way of } \\
\text { consolidation. } \\
\text { - QIB successfully re-certified for ISO 27001 for } \\
\text { the Information Security in the Alternate Channels } \\
\text { domain. Also, QIB get PCI DSS certification for } \\
\text { compliance to regulations related to Cards" (Qatar } \\
\text { Islamic Bank, 2012, p.32). }\end{array}$ & $\begin{array}{l}\text { Technology/ } \\
\text { information } \\
\text { technology }\end{array}$ & $\begin{array}{l}\text { 1: } \\
\text { Operational } \\
\text { risk item } \\
\text { disclosed by } \\
\text { bank } \\
\text { contains } \\
\text { qualitative } \\
\text { information. }\end{array}$ \\
\hline $\begin{array}{l}\text { Jordan } \\
\text { Islamic } \\
\text { Bank } \\
\text { (Jordan) }\end{array}$ & $\begin{array}{l}\text { "Lawsuits filed against the Bank } \\
\text { The value of the lawsuits filed against the bank } \\
\text { (self-constructed) amounted JD 10,348,893 and } \\
481,993 \text { as of December 31, } 2013 \text { and December } \\
31,2012 \text { respectively. In addition, the value of the } \\
\text { lawsuits filed against the bank (joint) amounted } \\
\text { JD } 633,121 \text { and JD } 399,720 \text { as of December 31, } \\
2013 \text { and December } 31,2012 \text { respectively. In the } \\
\text { opinion of the Bank's management and attorney, } \\
\text { consequences incurred by the cases of joint } \\
\text { investment accounts are booked on the Investment } \\
\text { Risks Fund. What the Bank may incur will be } \\
\text { covered from the Bank's provisions. The Bank } \\
\text { shall not incur any amounts for the lawsuits filed } \\
\text { against it (self-constructed)" (Jordan Islamic } \\
\text { Bank, 2013, p. 151). }\end{array}$ & Legal risks & $\begin{array}{l}2: \\
\text { Operational } \\
\text { risk item } \\
\text { disclosed by } \\
\text { bank } \\
\text { contains } \\
\text { qualitative } \\
\text { information. }\end{array}$ \\
\hline
\end{tabular}




\section{References}

Abdallah, A., Hassan, M. K., \& McClelland, P. L. (2015). Islamic financial institutions, corporate governance, and corporate risk disclosure in Gulf Cooperation Council countries. Journal of Multinational Financial Management, 31, 63-82.

Abdou, H. A., Mitra, S., Fry, J., \& Elamer, A. A. (2019). Would two-stage scoring models alleviate bank exposure to bad debt? Expert Systems with Applications, 128, 1-13.

Abdullah, W., Percy, M., \& Stewart, J. (2015). Determinants of voluntary corporate governance disclosure: Evidence from Islamic banks in the Southeast Asian and the Gulf Cooperation Council regions. Journal of Contemporary Accounting \& Economics, 11(3), 262-279.

Abedifar, P., Molyneux, P., \& Tarazi, A. (2013). Risk in Islamic banking. Review of Finance, 17 (6), 2035-2096.

Adhikariparajul, M., Hassan, A., Fletcher, M., \& Elamer, A. A. (2019). Integrated reporting in UK higher education institutions. Sustainability Accounting, Management and Policy Journal, Forthcoming. https://doi.org/10.1108/SAMPJ-03-2018-0093.

Alnabsha, A., Abdou, H. A., Ntim, C. G., \& Elamer, A. A. (2018). Corporate boards, ownership structures and corporate disclosures: Evidence from a developing country. Journal of Applied Accounting Research, 19(1), 20-41.

AI-Bassam, W. M., \& Ntim, C. G. (2016). The effect of Islamic values on voluntary corporate governance disclosure: The case of Saudi listed firms. Journal of Islamic Accounting and Business Research, Forthcoming.

Al-Hadi, A., Taylor, G., \& Al-Yahyaee, K. H. (2016). Ruling family political connections and risk reporting: Evidence from the GCC. The International Journal of Accounting, 51(4), 504-524.

Al-Malkawi, H.-A. N., Pillai, R., \& Bhatti, M. (2014). Corporate governance practices in emerging markets: The case of GCC countries. Economic Modelling, 38, 133-141.

Alshbili, I., Elamer, A. A., \& Beddewela, E. (2019). Ownership types, corporate governance and corporate social responsibility disclosures: Empirical evidence from a developing country. Accounting Research Journal, Forthcoming. https://doi.org/10.1108/ARJ-032018-0060.

Arellano, M., \& Bover, O. (1995). Another look at the instrumental variable estimation of error-components models. Journal of Econometrics, 68(1), 29-51.

Barakat, A., \& Hussainey, K. (2013). Bank governance, regulation, supervision, and risk reporting: Evidence from operational risk disclosures in European banks. International Review of Financial Analysis, 30, 254-273.

BCBS. (2003). Sound practices for the management and supervision of operational risk. Basel Committee on Banking Supervision, Basel. Switzerland.

BCBS. (2006). International convergence of capital measurement and capital standards: A revised framework. Basel Committee on Banking Supervision, Basel. Switzerland.

BCBS. (2011). Principles for the sound management of operational risk. Basel Committee on Banking Supervision, Basel. Switzerland.

BCBS. (2014). Operational risk - Revisions to the simpler approaches. Basel Committee on Banking Supervision.

BCBS. (2015a). FSI Survey: Basel II, 2.5 and III implementation. Basel Committee on Banking Supervision, Basel. Switzerland.

BCBS. (2015b). Revised Pillar 3 disclosure requirements. Basel Committee on Banking Supervision, Basel. Switzerland. 
BCBS. (2016). Pillar 3 disclosure requirements - consolidated and enhanced framework (Consultative Document). Basel Committee on Banking Supervision, Basel. Switzerland.

Bitar, M., Saad, W., \& Benlemlih, M. (2016). Bank risk and performance in the MENA region: The importance of capital requirements. Economic Systems, 40(3), 398-421.

Bischof, J. (2009). The effects of IFRS 7 adoption on bank disclosure in Europe. Accounting in Europe, 6(2), 167-194.

Cheng, E. C., \& Courtenay, S. M. (2006). Board composition, regulatory regime and voluntary disclosure. International Journal of Accounting, 41(3), 262-289.

Connelly, B. L., Certo, S. T., Ireland, R. D., \& Reutzel, C. R. (2011). Signaling theory: A review and assessment. Journal of Management, 37(1), 39-67.

Dalwai, T. A. R., Basiruddin, R., \& Abdul Rasid, S. Z. (2015). A critical review of relationship between corporate governance and firm performance: GCC banking sector perspective. Corporate Governance, 15(1), 18-30.

Distinguin, I., Hasan, I., \& Tarazi, A. (2010). The use of accounting data to predict bank financial distress in MENA countries. International Journal of Banking, Accounting and Finance, 2(4), 332-356.

Domínguez, L. R., \& Gámez, L. C. N. (2014). Corporate reporting on risks: Evidence from Spanish companies. Revista de Contabilidad, 17(2), 116-129.

EIoD. (2016). Code of corporate governance for listed companies. Egyptian Institute of Directors, http://www.eiod.org/uploads/documents/code\%202016.pdf.

Elamer, A. A. (2017). Empirical essays on risk disclosures, multi-level governance, credit ratings, and bank value: evidence from MENA banks. University of Huddersfield.

Elamer, A. A., \& Benyazid, I. (2018). The impact of risk committee on financial performance of UK financial institutions. International Journal of Accounting and Finance, 8(2), 161-180. https://doi.org/10.1504/ijaf.2018.093290

Elamer, A. A., AlHares, A., Ntim, C. G., \& Benyazid, I. (2018). The corporate governancerisk-taking nexus: evidence from insurance companies. International Journal of Ethics and Systems, 34(4), 493-509.

Elamer, A. A., Ntim, C. G., \& Abdou, H. A. (2017). Islamic governance, national governance, and bank risk management and disclosure in MENA countries. Business \& Society. Forthcoming.

Elamer, A. A., Ntim, C. G., Abdou, H. A., Zalata, A., \& Elmagrhi, M. H. (2019). The impact of multi-layer governance on bank risk disclosure in emerging markets: The case of Middle East and North Africa. Accounting Forum, 43(2), 246-281.

Elmagrhi, M. H., Ntim, C. G., Elamer, A. A., \& Zhang, Q. (2019). A study of environmental policies and regulations, governance structures and environmental performance: The role of female directors. Business Strategy and the Environment, 28(1), 206-220.

Ernst \& Young (2016). World Islamic Banking Competitiveness Report 2016: New realities New opportunities. https://www.ey.com/Publication/vwLUAssets/ey-world-islamicbanking-competitiveness-report-2016/\$FILE/ey-world-islamic-bankingcompetitiveness-report-2016.pdf

Ernstberger, J., \& Grüning, M. (2013). How do firm-and country-level governance mechanisms affect firms' disclosure? Journal of Accounting and Public Policy, 32(3), 50-67.

Fama, E. F., \& Jensen, M. C. (1985). Organizational forms and investment decisions. Journal of financial Economics, 14(1), 101-119.

Farook, S., Kabir Hassan, M., \& Lanis, R. (2011). Determinants of corporate social responsibility disclosure: the case of Islamic banks. Journal of Islamic Accounting and Business Research, 2(2), 114-141. 
Ford, G., Sundmacher, M., Finch, N., \& Carlin, T. M. (2009). Operational risk disclosure in financial services firms. Operational risk toward Basel III: Best practices and issues in modeling, management and regulation, 381-395.

Global Islamic Finance Report (2017). Overview of the global Islamic finance industry http://www.gifr.net/publications/gifr2017/intro.pdf

Grassa, R., \& Chakroun, R. (2016). Ownership structure, board's characteristics and corporate governance disclosure in GCC banks: what about Islamic banks?. International Journal of Accounting, Auditing and Performance Evaluation, 12(4), 360-395.

Grassa, R., Chakroun, R., \& Hussainey, K. (2018). Corporate governance and Islamic banks' products and services disclosure. Accounting Research Journal, 31(1), 75-89.

Haniffa, R. M., \& Cooke, T. E. (2002). Culture, corporate governance and disclosure in Malaysian corporations. Abacus, 38(3), 317-349.

Haniffa, R., \& Hudaib, M. (2007). Exploring the ethical identity of Islamic banks via communication in annual reports. Journal of Business Ethics, 76(1), 97-116.

Haque, F., \& Brown, K. (2017). Bank ownership, regulation and efficiency: Perspectives from the Middle East and North Africa (MENA) Region. International Review of Economics \& Finance, 47, 273-293.

Helbok, G., \& Wagner, C. (2006). Determinants of operational risk reporting in the banking industry. Available at SSRN 425720.

Htay, S. N. N., Rashid, H. M. A., Adnan, M. A., \& Meera, A. K. M. (2012). Impact of corporate governance on social and environmental information disclosure of Malaysian listed banks: Panel data analysis. Asian Journal of Finance \& Accounting, 4(1), 1-24.

IFSB. (2005). Guiding principles of risk management for institutions (Other than Insurance Institutions) offering only Islamic financial services. Islamic Financial Services Board (http://www.ifsb.org/standard/ifsb1.pdf).

Iren, P., Reichert, A. K., \& Gramlich, D. (2014). Information disclosure, bank performance and bank stability. International Journal of Banking, Accounting and Finance, 5(4), 374-417.

Izhar, H., \& Asutay, M. (2010). A theoretical analysis of the operational risk framework in Islamic banks. International Journal of Economics, Management and Accounting, 18(1), 73-113.

Jensen, M. C. (1993). The modern industrial revolution, exit, and the failure of internal control systems. the Journal of Finance, 48(3), 831-880.

Jensen, M. C., \& Meckling, W. H. (1976). Theory of the firm: Managerial behavior, agency costs and ownership structure. Journal of Financial Economics, 3(4), 305-360.

Kaufmann, D., Kraay, A., \& Mastruzzi, M. (2011). The worldwide governance indicators: methodology and analytical issues. Hague Journal on the Rule of Law, 3(02), 220-246.

Larcker, D. F., \& Rusticus, T. O. (2010). On the use of instrumental variables in accounting research. Journal of Accounting and Economics, 49(3), 186-205.

Mallin, C., Farag, H., \& Ow-Yong, K. (2014). Corporate social responsibility and financial performance in Islamic banks. Journal of Economic Behavior \& Organization, 103, S21-S38.

McLaughlin, C., Elamer, A. A., Glen, T., AlHares, A., \& Gaber, H. R. (2019). Accounting society's acceptability of carbon taxes: Expectations and reality. Energy Policy, 131, 302-311.

Mokhtar, E., \& Mellett, H. (2013). Competition, corporate governance, ownership structure and risk reporting. Managerial Auditing Journal, 28(9), 838-865.

Mokni, R., Echchabi, A., Azouzi, D., \& Rachdi, H. (2014). Risk management tools practiced in Islamic banks: evidence in MENA region. Journal of Islamic Accounting and Business Research, 5(1), 77-97. 
Mollah, S., \& Zaman, M. (2015). Shari'ah supervision, corporate governance and performance: Conventional vs. Islamic banks. Journal of Banking \& Finance, 58, 418-435.

Ntim, C. G. (2016). Corporate governance, corporate health accounting, and firm value: The case of HIV/AIDS disclosures in Sub-Saharan Africa. The International Journal of Accounting, 51(2), 155-216.

Ntim, C. G., \& Soobaroyen, T. (2013). Corporate governance and performance in socially responsible corporations: New empirical insights from a Neo-Institutional framework. Corporate Governance: An International Review, 21(5), 468-494.

Ntim, C. G., Lindop, S., \& Thomas, D. A. (2013). Corporate governance and risk reporting in South Africa: A study of corporate risk disclosures in the pre-and post-2007/2008 global financial crisis periods. International Review of Financial Analysis, 30, 363-383.

O’Sullivan, M., Percy, M., \& Stewart, J. (2008). Australian evidence on corporate governance attributes and their association with forward-looking information in the annual report. Journal of Management \& Governance, 12(1), 5-35.

OCED. (2015). G20/OECD principles of corporate governance, OECD Publishing, Paris. http://dx.doi.org/10.1787/9789264236882-en.

Pfeffer, J., \& Salancik, G. R. (2003). The external control of organizations: A resource dependence perspective: Stanford University Press.

Rahman, A. A., \& Bukair, A. A. (2013). The influence of the Shariah supervision board on corporate social responsibility disclosure by Islamic banks of Gulf Co-operation Council countries. Asian Journal of Business and Accounting, 6(2).

S\&P (2016). Islamic Finance Outlook. 2017 Edition. https://www.spratings.com//documents/20184/0/Islamic+Finance+Outlook+2017/5ab be572-c826-4622-bd13-1aba725281fc

Safieddine, A. (2009). Islamic financial institutions and corporate governance: New insights for agency theory. Corporate Governance: An International Review, 17(2), 142-158.

Shehata, N. F. (2015). Development of corporate governance codes in the GCC: an overview. Corporate Governance: The International Journal of Business in Society, 15(3), 315338.

Tunyi, A. A., \& Ntim, C. G. (2016). Location advantages, governance quality, stock market development and firm characteristics as antecedents of African M\&As. Journal of International Management, 22(2), 147-167.

Van Greuning, H., \& Iqbal, Z. (2007). Banking and the risk environment. Islamic Finance: The Regulatory Challenge, John Wiley \& Sons, Singapore, 11-39.

Wintoki, M.B., Linck, J.S., \& Netter, J.M. (2012). Endogeneity and the dynamics of internal corporate governance. Journal of Financial Economics, 105(3), 581-606.

Young, J. (2015). Guiding criteria for operational risk reporting in a corporate environment. Corporate Ownership and Control, 13(1), 881-896.

Zouari, S., \& Taktak, N. (2014). Ownership structure and financial performance in Islamic banks: Does bank ownership matter?. International Journal of Islamic and Middle Eastern Finance and Management, 7(2), 146-160. 


\section{Tables:}

Table 1: Worldwide governance indicators across MENA countries

\begin{tabular}{lcccccccccccc}
\hline $\begin{array}{l}\text { Governance } \\
\text { Indicators }\end{array}$ & \multicolumn{2}{l}{ Year } & MENA & Bahrain & Egypt & \multicolumn{2}{l}{ Jordan } & Kuwait & Lebanon & Oman & Qatar KSA Syria UAE & KA \\
\hline Political Stability & 2006 & 37 & 32 & 21 & 23 & 57 & 5 & 72 & 76 & 29 & 37 & 77 \\
and Absence of & 2009 & 38 & 40 & 26 & 32 & 55 & 8 & 74 & 91 & 28 & 28 & 81 \\
Terrorism & 2013 & 28 & 9 & 7 & 26 & 52 & 6 & 63 & 92 & 34 & 0 & 76 \\
\hline & 2006 & 43 & 71 & 37 & 62 & 61 & 48 & 68 & 62 & 52 & 7 & 70 \\
& 2009 & 48 & 74 & 47 & 61 & 56 & 53 & 69 & 73 & 57 & 18 & 66 \\
Regulatory Quality & 2013 & 44 & 71 & 26 & 56 & 50 & 50 & 67 & 74 & 55 & 0 & 75 \\
\hline
\end{tabular}

Source: Worldwide Governance Indicators (WGI), World Bank Group, (2015). 
Table 2: Basel II implementation in the MENA region

\begin{tabular}{lcccccccccc}
\hline Country & Bahrain & Egypt & Jordan & Kuwait & Lebanon & Oman & Qatar & $\begin{array}{c}\text { Saudi } \\
\text { Arabia }\end{array}$ & Syria & UAE \\
\hline $\begin{array}{l}\text { Date of } \\
\text { implementation }\end{array}$ & 2008 & 2012 & 2008 & 2006 & 2007 & 2006 & 2006 & 2006 & -- & 2009 \\
\hline
\end{tabular}

Source: BCBS (2015a) 
Table 3: Sample characteristics

\begin{tabular}{lrrr}
\hline Country & Banks & Bank obs & Percentage \\
\hline Bahrain & 8 & 60 & $14.56 \%$ \\
Egypt & 6 & 33 & $8.01 \%$ \\
Jordan & 3 & 16 & $3.88 \%$ \\
Kuwait & 6 & 41 & $9.95 \%$ \\
Lebanon & 2 & 16 & $3.88 \%$ \\
Oman & 4 & 5 & $1.21 \%$ \\
Qatar & 8 & 52 & $12.62 \%$ \\
Saudi Arabia & 11 & 84 & $20.39 \%$ \\
Syria & 1 & 1 & $0.24 \%$ \\
UAE & 14 & 104 & $25.24 \%$ \\
\hline Sum & $\mathbf{6 3}$ & $\mathbf{4 1 2}$ & $\mathbf{1 0 0 . 0 0 \%}$ \\
\hline
\end{tabular}


Table 4: Summary of definitions and operationalisation of variables

\begin{tabular}{|c|c|}
\hline Variables & Definitions and coding \\
\hline \multicolumn{2}{|c|}{ Panel A: Operational risk disclosure } \\
\hline \multirow[t]{2}{*}{ ORDs } & $\begin{array}{l}\text { Is the overall operational risk disclosure score determined depending on the index as shown } \\
\text { in Appendix A, which fairly capture the comparative weights of different operational risk } \\
\text { categories. } \\
\text { For the un-weighted operational risk disclosure index, each of the } 22 \text { items has a score } \\
\text { ranging from } 0 \text { to } 1 \text { (i.e., } 0 \text { - operational risk item not disclosed by a bank; } 1 \text { - operational } \\
\text { risk item disclosed by a bank). This un-weighted scoring procedure can result in a total } \\
\text { potential score of } 22 \text {. }\end{array}$ \\
\hline & $\begin{array}{l}\text { For the weighted operational risk disclosure index, each of the } 22 \text { items has a score ranging } \\
\text { from } 0 \text { to } 2 \text { (i.e., } 0 \text { - operational risk item not disclosed by a bank; } 1 \text { - operational risk item } \\
\text { disclosed by a bank and contains past, future, good, bad and/or qualitative information; } 2 \text { - } \\
\text { operational risk item disclosed by a bank and contains past, future, good, bad, qualitative } \\
\text { and/or quantitative information). This weighted scoring procedure can result in a total } \\
\text { potential score of } 44 \text {. These ORD items and the scoring procedure are contained in the } \\
\text { Appendix. }\end{array}$ \\
\hline \multicolumn{2}{|c|}{ Panel B: Sharia supervisory board } \\
\hline SSBE & SSB existence is a dummy variable which takes 1 , if a bank has SSB board, 0 otherwise \\
\hline SSBM & SSB's members is number of the SSB members \\
\hline SSBT & SSB's meetings is number of the SSB meetings \\
\hline \multicolumn{2}{|c|}{ Panel C: Governance variables. } \\
\hline BLCK & Percentage of shareholders holds $5 \%$ at least of the full bank ordinary shareholdings. \\
\hline BOSZ & Number of the bank board of directors. \\
\hline NEDs & Percentage of non-executive directors to the bank board of directors' size. \\
\hline \multicolumn{2}{|c|}{ Panel D: Country-level Governance $(C L G)$} \\
\hline CLG & $\begin{array}{l}\text { Country- level Governance }(C L G) \text { is a composite measure based on Kaufmann et al. (2011) } \\
\text { which calculates the six dimensions of country governance. The six dimensions of country } \\
\text { governance }(C L G) \text { are defined as follows: Voice and accountability }(V A) \text {, political stability } \\
(P S) \text {, government quality }(G E) \text {, regulatory quality }(R Q) \text {, rule of law }(R O L) \text {, and control of } \\
\text { corruption }(C O C) \text {. A higher score means better country governance. }\end{array}$ \\
\hline \multicolumn{2}{|c|}{ Panel E: Control variables } \\
\hline SIZE & Bank size measured by natural log of total assets. \\
\hline ROA & $\begin{array}{l}\text { Performance which is measured by return on average assets which are a percentage of net } \\
\text { income to total asset. }\end{array}$ \\
\hline LIQ & Liquidity which is measured by net loans to total assets. \\
\hline INCD & Income diversity which is percentage of net non-interest income/average earning assets. \\
\hline COST & Operations efficiency which is percentage of cost to income. \\
\hline CRS & 1, for the crisis period $(2007-2008), 0$ otherwise. \\
\hline GCC & $\begin{array}{l}\text { 1, if a bank in one of GCC countries (Bahrain, Kuwait, Oman, Qatar, Saudi Arabia, UAE), } \\
0 \text { otherwise. }\end{array}$ \\
\hline YD & Dummies for each of the fiscal years 2006-2013. \\
\hline INFL & Inflation, which is consumer prices (annual \%). \\
\hline GDPC & GDP per capita (current US\$). \\
\hline
\end{tabular}


Table 5: PCA (eigenvectors) and diagnostics of the national governance quality dimensions

\begin{tabular}{lrrrrrrrr}
\hline Variables & Comp $_{1}$ & Comp $_{2}$ & Comp $_{3}$ & Comp $_{4}$ & Comp $_{5}$ & Comp $_{6}$ & Unexplained & KMO \\
\hline VA & 0.1761 & 0.9789 & 0.0603 & 0.0746 & -0.0351 & -0.0191 & 0 & 0.8226 \\
PS & 0.4277 & -0.0079 & -0.6585 & -0.0541 & 0.599 & 0.1475 & 0 & 0.7523 \\
GE & 0.4545 & -0.0665 & 0.2026 & -0.5304 & 0.0176 & -0.6829 & 0 & 0.6687 \\
RQ & 0.4194 & -0.1108 & 0.6994 & 0.1779 & 0.3931 & 0.3694 & 0 & 0.6309 \\
ROL & 0.4354 & -0.1453 & -0.1301 & 0.7551 & -0.3065 & -0.3291 & 0 & 0.6658 \\
COC & 0.4627 & -0.0628 & -0.125 & -0.3292 & -0.6255 & 0.5165 & 0 & 0.7950 \\
Eigenvalue & 4.3360 & 0.9002 & 0.4162 & 0.2499 & 0.0698 & 0.0280 & & \\
Proportion & 0.7227 & 0.1500 & 0.0694 & 0.0416 & 0.0116 & 0.0047 & & \\
KMO & & & & & & & & 0.7029
\end{tabular}

Notes: This table reports the six dimensions of national governance quality indicators (CLG) PCA (eigenvectors). Comp refers to component. The six dimensions of national governance quality indicators $(C L G)$ are defined as follows: Voice and accountability quality $(V A)$, political stability quality $(P S Q)$, government quality $(G E)$, regulatory quality $(R Q)$, rule of law quality $(R O L)$, and control of corruption quality $(C O C)$. Also, the Kaiser-Meyer-Olkin measure $(K M O)$ is a measure of sampling adequacy. 
Table 6: Summary descriptive statistics of all variables for 412 Islamic bank years

\begin{tabular}{|c|c|c|c|c|}
\hline Variables & Mean & STD & Min & Max \\
\hline$\overline{\text { ORD }}$ & 11.82 & 4.75 & 0.00 & 22.00 \\
\hline SSBE & 0.69 & 0.46 & 0.00 & 1.00 \\
\hline SSBM & 2.55 & 1.94 & 0.00 & 7.00 \\
\hline SSBT & 5.55 & 2.74 & 0.00 & 18.00 \\
\hline BLCK & 53.32 & 26.89 & 0.00 & 100.00 \\
\hline BOSZ & 9.46 & 1.73 & 5.00 & 15.00 \\
\hline NEDs & 0.88 & 0.19 & 0.00 & 1.00 \\
\hline CLG & 0.33 & 0.39 & -0.95 & 0.80 \\
\hline SIZE & 16.12 & 1.49 & 3.73 & 21.09 \\
\hline INCD & 0.09 & 0.21 & -0.30 & 0.46 \\
\hline ROA & 3.82 & 2.19 & -4.30 & 13.53 \\
\hline LIQ & 53.41 & 15.74 & 0.00 & 79.93 \\
\hline COST & 41.03 & 38.28 & -365.63 & 284.00 \\
\hline GCC & 0.83 & 0.37 & 0.00 & 1.00 \\
\hline INFL & 4.70 & 4.11 & -4.90 & 15.10 \\
\hline GDPC & 28384.41 & 24730.12 & 1472.60 & 93714.10 \\
\hline
\end{tabular}


Table 7: Pearson's and Spearman's correlation matrices of the variables for all 412 Islamic bank years

\begin{tabular}{|c|c|c|c|c|c|c|c|c|c|c|c|c|c|c|c|c|}
\hline Variables & ORD & SSBE & SSBM & SSBT & BLCK & BOSZ & NEDs & CLG & $\overline{\text { SIZE }}$ & INCD & ROA & LIQ & COST & GCC & INFL & GDPC \\
\hline ORD & 1 & $0.38^{* *}$ & $0.38^{* *}$ & $0.28^{* *}$ & 0.08 & $-0.15^{* *}$ & $0.36^{* *}$ & $0.18^{* *}$ & $0.29^{* *}$ & $-0.15^{* *}$ & 0.02 & $0.23^{* *}$ & -0.01 & $0.33^{* *}$ & $-0.42^{* *}$ & -0.03 \\
\hline SSBE & $0.33^{* *}$ & 1 & $0.52^{* *}$ & $0.16^{* *}$ & 0.01 & $-0.18^{* *}$ & $0.16^{* *}$ & $0.22^{* *}$ & $0.21^{* *}$ & $-0.14^{* *}$ & -0.01 & 0.08 & -0.05 & $0.15^{* *}$ & $-0.18^{* *}$ & 0.03 \\
\hline SSBM & $0.38^{* *}$ & $0.51^{* *}$ & 1 & $0.36^{* *}$ & 0.03 & $-0.28^{* *}$ & 0.10 & $0.23^{* *}$ & 0.09 & $-0.16^{* *}$ & -0.07 & 0.03 & 0.07 & $0.16^{* *}$ & $-0.20^{* *}$ & 0.02 \\
\hline SSBT & $0.28^{* *}$ & $0.16^{* *}$ & $0.33^{* *}$ & 1 & -0.02 & -0.05 & $0.13^{* *}$ & $0.16^{* *}$ & $0.20^{* * *}$ & $-0.12^{*}$ & -0.03 & 0.04 & -0.02 & 0.07 & $-0.17^{* *}$ & $0.13^{*}$ \\
\hline BLCK & $0.11^{*}$ & -0.02 & -0.02 & -0.04 & 1 & $0.13^{* *}$ & 0.04 & 0.01 & -0.01 & 0.01 & 0.02 & -0.01 & 0.06 & $-0.32^{* * *}$ & 0.06 & $-0.46^{* *}$ \\
\hline BOSZ & $-0.13^{* *}$ & $-0.18^{* *}$ & $-0.27^{* * *}$ & -0.08 & $0.17^{* *}$ & 1 & 0.03 & $-0.13^{* *}$ & $0.16^{\text {*** }}$ & -0.05 & $0.14^{* *}$ & $0.11^{*}$ & $-0.13^{* *}$ & -0.03 & 0.08 & $-0.11^{*}$ \\
\hline NEDs & $0.26^{* *}$ & $0.10^{*}$ & 0.08 & $0.28^{* * *}$ & -0.03 & -0.05 & 1 & 0.08 & 0.09 & 0.04 & 0.01 & $0.23^{* *}$ & -0.08 & $0.18^{* *}$ & $-0.23^{* *}$ & -0.03 \\
\hline CLG & $0.17^{* *}$ & $0.22^{* *}$ & $0.24^{* *}$ & $0.13^{* *}$ & 0.01 & $-0.12^{*}$ & 0.02 & 1 & $0.13^{* *}$ & -0.02 & 0.02 & $-0.19^{* *}$ & $-0.12^{*}$ & $-0.13^{* *}$ & 0.04 & $-0.14^{* *}$ \\
\hline SIZE & $0.30^{* *}$ & $0.25^{* *}$ & $0.12^{*}$ & $0.24^{* * *}$ & -0.01 & $0.22^{* *}$ & 0.03 & $0.17^{* *}$ & 1 & $-0.19^{* *}$ & $0.20^{* *}$ & $0.26^{* *}$ & $-0.16^{* *}$ & $0.26^{* *}$ & $-0.18^{* *}$ & 0.05 \\
\hline INCD & $-0.22^{* *}$ & $-0.12^{*}$ & $-0.14^{* *}$ & -0.03 & -0.09 & -0.09 & $0.20^{* *}$ & $-0.11^{* *}$ & $-0.23^{* *}$ & 1 & $0.15^{* *}$ & $0.15^{* *}$ & -0.03 & $-0.22^{* * *}$ & $0.13^{* *}$ & $-0.13^{* * *}$ \\
\hline ROA & $-0.17^{* *}$ & -0.05 & $-0.14^{* *}$ & 0.01 & -0.05 & $0.17^{* *}$ & 0.02 & 0.02 & $0.27^{* *}$ & $0.20^{* * *}$ & 1 & $0.26^{* *}$ & $-0.32^{* *}$ & $0.13^{* *}$ & 0.02 & $0.12^{*}$ \\
\hline LIQ & $0.23^{* *}$ & 0.07 & -0.01 & 0.06 & $-0.11^{*}$ & $0.12^{*}$ & $0.33^{* *}$ & $-0.11^{*}$ & $0.27^{* *}$ & $0.22^{* *}$ & $0.25^{* *}$ & 1 & $-0.15^{* *}$ & $0.53^{* *}$ & $-0.11^{*}$ & $0.25^{\text {** }}$ \\
\hline COST & 0.09 & -0.02 & $0.14^{* *}$ & -0.01 & $0.19^{* *}$ & $-0.20^{* *}$ & -0.01 & -0.01 & $-0.31^{* *}$ & $-0.12^{*}$ & $-0.56^{* *}$ & $-0.29^{* * *}$ & 1 & -0.08 & 0.04 & $-0.21^{* * *}$ \\
\hline GCC & $0.26^{* *}$ & $0.15^{* *}$ & $0.16^{* *}$ & 0.07 & $-0.35^{* *}$ & -0.02 & $0.16^{* * *}$ & -0.05 & $0.31^{* *}$ & $-0.14^{* *}$ & $0.11^{*}$ & $0.52^{* *}$ & $-0.22^{* *}$ & 1 & $-0.32^{* * *}$ & $0.42^{* *}$ \\
\hline INFL & $-0.33^{* *}$ & $-0.14^{* * *}$ & $-0.12^{*}$ & $-0.17^{* *}$ & $0.10^{*}$ & 0.01 & $-0.27^{* *}$ & $0.13^{* *}$ & $-0.15^{* *}$ & 0.02 & $0.13^{* *}$ & $-0.17^{* * *}$ & 0.04 & $-0.36^{* * *}$ & 1 & 0.08 \\
\hline GDPC & 0.03 & $0.10^{*}$ & $0.12^{*}$ & $0.16^{\text {** }}$ & $-0.43^{* *}$ & $-0.14^{* * *}$ & $0.13^{\text {** }}$ & -0.02 & $0.11^{*}$ & $-0.14^{* *}$ & $0.16^{* *}$ & $0.28^{* *}$ & $-0.24^{* * *}$ & $0.53^{* *}$ & 0.09 & 1 \\
\hline
\end{tabular}

Notes: The upper right half of the table reports Pearson's parametric correlation coefficients, whilst the bottom left half of the table presents Spearman's non-parametric correlation coefficients. ** and * indicate correlation is significant at the $1 \%$, and 5\% levels, respectively (two-tailed tests). Variables are defined as follows: operational risk disclosure (ORD), SSB report (SSBR), SSB existence ( $S S B E)$, SSB members ( $S S B M)$, SSB meetings ( $S S B T)$, board size (BOSZ), non-executive directors (NEDs), block ownership $(B L C K)$, political stability and absence of violence/terrorism $(P S)$ regulatory quality $(R Q)$, bank size (SIZE), performance $(R O A)$, income diversity (INCD), liquidity (LIQ), operations efficiency (COST), Gulf Cooperation Council (GCC), inflation (INFL), and GDP per capita $(G D P C)$. Table 4 fully defines all the variables used. 
Table 8: The impact of SSBs and governance structures on ORDs using fixed effect regression

\begin{tabular}{|c|c|c|c|c|c|c|}
\hline \multirow[t]{2}{*}{ Variables } & \multicolumn{3}{|c|}{ Dependent variable: Unweighted ORDs } & \multicolumn{3}{|c|}{ Dependent variable: Weighted ORDs } \\
\hline & (1) & $(2)$ & (3) & (4) & (5) & (6) \\
\hline \multicolumn{7}{|c|}{ Panel A: Islamic Governance (Sharia Supervisory Board) } \\
\hline SSBE & $\begin{array}{l}8.78 * * * \\
(0.000)\end{array}$ & & & $\begin{array}{l}8.66 * * * \\
(0.000)\end{array}$ & & \\
\hline SSBM & & $\begin{array}{l}11.71 * * * \\
(0.000)\end{array}$ & & & $\begin{array}{l}11.12 * * * \\
(0.000)\end{array}$ & \\
\hline SSBT & & & $\begin{array}{c}2.43 * * \\
(0.016)\end{array}$ & & & $\begin{array}{c}2.22 * * \\
(0.027)\end{array}$ \\
\hline \multicolumn{7}{|c|}{ Panel B: Governance Structures } \\
\hline BLCK & $\begin{array}{l}-0.38 \\
(0.702)\end{array}$ & $\begin{array}{l}1.03 \\
(0.302)\end{array}$ & $\begin{array}{l}-0.21 \\
(0.836)\end{array}$ & $\begin{array}{l}0.01 \\
(0.988)\end{array}$ & $\begin{array}{l}1.40 \\
(0.162)\end{array}$ & $\begin{array}{l}0.16 \\
(0.875)\end{array}$ \\
\hline BOSZ & $\begin{array}{l}-1.43 \\
(0.155)\end{array}$ & $\begin{array}{l}-0.66 \\
(0.511)\end{array}$ & $\begin{array}{l}-1.49 \\
(0.138)\end{array}$ & $\begin{array}{l}-1.26 \\
(0.207)\end{array}$ & $\begin{array}{l}-0.52 \\
(0.604)\end{array}$ & $\begin{array}{l}-1.30 \\
(0.195)\end{array}$ \\
\hline NEDs & $\begin{array}{c}1.88 * \\
(0.061)\end{array}$ & $\begin{array}{c}1.69 * \\
(0.091)\end{array}$ & $\begin{array}{l}2.67 * * * \\
(0.008)\end{array}$ & $\begin{array}{c}1.75^{*} \\
(0.081)\end{array}$ & $\begin{array}{c}1.57 \\
(0.117)\end{array}$ & $\begin{array}{c}2.59 * * \\
(0.010)\end{array}$ \\
\hline \multicolumn{7}{|c|}{ Panel C: Country-level Governance } \\
\hline CLG & $\begin{array}{l}6.18 * * * \\
(0.000)\end{array}$ & $\begin{array}{l}5.62 * * * \\
(0.000)\end{array}$ & $\begin{array}{l}6.32 * * * \\
(0.000)\end{array}$ & $\begin{array}{l}7.02 * * * \\
(0.000)\end{array}$ & $\begin{array}{l}6.64 * * * \\
(0.000)\end{array}$ & $\begin{array}{l}7.11 * * * \\
(0.000)\end{array}$ \\
\hline \multicolumn{7}{|c|}{ Panel D: Control Variables } \\
\hline SIZE & $\begin{array}{c}1.38 \\
(0.168)\end{array}$ & $\begin{array}{l}4.17 * * * \\
(0.000)\end{array}$ & $\begin{array}{l}3.10 * * * \\
(0.002)\end{array}$ & $\begin{array}{l}1.14 \\
(0.257)\end{array}$ & $\begin{array}{l}3.81 * * * \\
(0.000)\end{array}$ & $\begin{array}{l}2.82 * * * \\
(0.005)\end{array}$ \\
\hline ROA & $\begin{array}{l}-1.29 \\
(0.198)\end{array}$ & $\begin{array}{l}-1.08 \\
(0.283)\end{array}$ & $\begin{array}{l}-1.04 \\
(0.301)\end{array}$ & $\begin{array}{l}-1.89 * \\
(0.059)\end{array}$ & $\begin{array}{l}-1.72 * \\
(0.086)\end{array}$ & $\begin{array}{l}-1.60 \\
(0.110)\end{array}$ \\
\hline INCD & $\begin{array}{l}-1.83^{*} \\
(0.068)\end{array}$ & $\begin{array}{l}-0.89 \\
(0.373)\end{array}$ & $\begin{array}{l}-2.10 * * \\
(0.037)\end{array}$ & $\begin{array}{l}-1.40 \\
(0.162)\end{array}$ & $\begin{array}{l}-0.48 \\
(0.629)\end{array}$ & $\begin{array}{l}-1.71 * \\
(0.088)\end{array}$ \\
\hline LIQ & $\begin{array}{l}4.09 * * * \\
(0.000)\end{array}$ & $\begin{array}{c}2.47 * * \\
(0.014)\end{array}$ & $\begin{array}{l}4.43 * * * \\
(0.000)\end{array}$ & $\begin{array}{l}4.15^{* * *} * \\
(0.000)\end{array}$ & $\begin{array}{c}2.58 * * \\
(0.010)\end{array}$ & $\begin{array}{l}4.48 * * * \\
(0.000)\end{array}$ \\
\hline COST & $\begin{array}{c}0.60 \\
(0.552)\end{array}$ & $\begin{array}{c}0.86 \\
(0.388)\end{array}$ & $\begin{array}{l}0.38 \\
(0.705)\end{array}$ & $\begin{array}{c}0.82 \\
(0.414)\end{array}$ & $\begin{array}{c}1.07 \\
(0.283)\end{array}$ & $\begin{array}{c}0.57 \\
(0.566)\end{array}$ \\
\hline GCC & Omitted & Omitted & Omitted & Omitted & Omitted & Omitted \\
\hline CRS & $\begin{array}{l}-4.48 * * * \\
(0.000)\end{array}$ & $\begin{array}{l}-3.88 * * * \\
(0.000)\end{array}$ & $\begin{array}{l}-4.12 * * * \\
(0.000)\end{array}$ & $\begin{array}{l}-4.83 * * * \\
(0.000)\end{array}$ & $\begin{array}{l}-4.23 * * * \\
(0.000)\end{array}$ & $\begin{array}{l}-4.43 * * * \\
(0.000)\end{array}$ \\
\hline INFL & $\begin{array}{l}-0.08 \\
(0.935)\end{array}$ & $\begin{array}{l}0.65 \\
(0.519)\end{array}$ & $\begin{array}{c}0.31 \\
(0.755)\end{array}$ & $\begin{array}{l}-0.38 \\
(0.703)\end{array}$ & $\begin{array}{l}0.30 \\
(0.767)\end{array}$ & $\begin{array}{l}-0.01 \\
(0.990)\end{array}$ \\
\hline GDPC & $\begin{array}{l}-1.18 \\
(0.238)\end{array}$ & $\begin{array}{l}-0.53 \\
(0.594)\end{array}$ & $\begin{array}{l}-2.20 * * \\
(0.028)\end{array}$ & $\begin{array}{l}-0.25 \\
(0.807)\end{array}$ & $\begin{array}{l}0.39 \\
(0.696)\end{array}$ & $\begin{array}{l}-1.30 \\
(0.195)\end{array}$ \\
\hline Fixed Effect & Year & Year & Year & Year & Year & Year \\
\hline Clustering & Bank & Bank & Bank & Bank & Bank & Bank \\
\hline Intercept & $\begin{array}{l}-0.01 \\
(0.989)\end{array}$ & $\begin{array}{l}-2.39 * * \\
(0.018)\end{array}$ & $\begin{array}{l}-1.19 \\
(0.234)\end{array}$ & $\begin{array}{l}-0.22 \\
(0.824)\end{array}$ & $\begin{array}{l}-2.53 * * \\
(0.012)\end{array}$ & $\begin{array}{l}-1.37 \\
(0.171)\end{array}$ \\
\hline F-value & $18.52 * * *$ & $24.96 * * *$ & $10.55^{* * *}$ & $18.97 * * *$ & $24.27 * * *$ & $11.09 * * *$ \\
\hline R-squared & 0.419 & 0.493 & 0.298 & 0.425 & 0.486 & 0.309 \\
\hline No. of obs. & 412 & 412 & 412 & 412 & 412 & 412 \\
\hline
\end{tabular}


Table 9: The impact of SSBs and governance structures on ORDs using 2SLS regression

\begin{tabular}{|c|c|c|c|c|c|c|}
\hline \multirow[t]{2}{*}{ Variables } & \multicolumn{3}{|c|}{ Dependent variable: Unweighted ORDs } & \multicolumn{3}{|c|}{ Dependent variable: Weighted ORDs } \\
\hline & (1) & (2) & (3) & (4) & (5) & (6) \\
\hline \multicolumn{7}{|c|}{ Panel A: Islamic Governance (Sharia Supervisory Board) } \\
\hline SSBE & $\begin{array}{l}9.08 * * * \\
(0.000)\end{array}$ & & & $\begin{array}{l}9.01 * * * \\
(0.000)\end{array}$ & & \\
\hline SSBM & & $\begin{array}{l}11.93 * * * \\
(0.000)\end{array}$ & & & $\begin{array}{l}11.47 * * * \\
(0.000)\end{array}$ & \\
\hline SSBT & & & $\begin{array}{l}2.65 * * * \\
(0.008)\end{array}$ & & & $\begin{array}{l}2.52 * * \\
(0.012)\end{array}$ \\
\hline \multicolumn{7}{|c|}{ Panel B: Governance Structures } \\
\hline BLCK & $\begin{array}{c}0.36 \\
(0.720)\end{array}$ & $\begin{array}{c}1.78^{*} \\
(0.075)\end{array}$ & $\begin{array}{c}1.09 \\
(0.274)\end{array}$ & $\begin{array}{l}0.46 \\
(0.645)\end{array}$ & $\begin{array}{l}1.85^{*} \\
(0.064)\end{array}$ & $\begin{array}{l}1.14 \\
(0.253)\end{array}$ \\
\hline BOSZ & $\begin{array}{l}-1.37 \\
(0.170)\end{array}$ & $\begin{array}{l}-0.41 \\
(0.684)\end{array}$ & $\begin{array}{l}-2.19 * * \\
(0.028)\end{array}$ & $\begin{array}{l}-1.43 \\
(0.154)\end{array}$ & $\begin{array}{l}-0.50 \\
(0.619)\end{array}$ & $\begin{array}{l}-2.29 * * \\
(0.022)\end{array}$ \\
\hline NEDs & $\begin{array}{l}2.64 * * * \\
(0.008)\end{array}$ & $\begin{array}{c}2.59 * * \\
(0.010)\end{array}$ & $\begin{array}{l}2.69 * * * \\
(0.007)\end{array}$ & $\begin{array}{l}2.47 * * \\
(0.014)\end{array}$ & $\begin{array}{l}2.43 * * \\
(0.015)\end{array}$ & $\begin{array}{l}2.54 * * \\
(0.011)\end{array}$ \\
\hline \multicolumn{7}{|c|}{ Panel C: Country-level Governance } \\
\hline$\overline{C L G}$ & $\begin{array}{c}2.14^{* *} \\
(0.032)\end{array}$ & $\begin{array}{c}1.48 \\
(0.139)\end{array}$ & $\begin{array}{l}2.75 * * * \\
(0.006)\end{array}$ & $\begin{array}{l}2.88 * * * \\
(0.004)\end{array}$ & $\begin{array}{l}2.27 * * \\
(0.023)\end{array}$ & $\begin{array}{l}3.53 * * * \\
(0.000)\end{array}$ \\
\hline \multicolumn{7}{|c|}{ Panel D: Control Variables } \\
\hline SIZE & $\begin{array}{l}1.35 \\
(0.178)\end{array}$ & $\begin{array}{l}3.44 * * * \\
(0.001)\end{array}$ & $\begin{array}{c}2.26 * * \\
(0.024)\end{array}$ & $\begin{array}{l}1.17 \\
(0.243)\end{array}$ & $\begin{array}{l}3.13 * * * \\
(0.002)\end{array}$ & $\begin{array}{l}2.01 * * \\
(0.045)\end{array}$ \\
\hline ROA & $\begin{array}{l}-1.55 \\
(0.120)\end{array}$ & $\begin{array}{l}-1.65 * \\
(0.099)\end{array}$ & $\begin{array}{l}-1.76 * \\
(0.079)\end{array}$ & $\begin{array}{l}-2.11 * * \\
(0.035)\end{array}$ & $\begin{array}{l}-2.25 * * \\
(0.024)\end{array}$ & $\begin{array}{l}-2.28 * * \\
(0.023)\end{array}$ \\
\hline INCD & $\begin{array}{l}-2.32 * * \\
(0.021)\end{array}$ & $\begin{array}{l}-0.84 \\
(0.402)\end{array}$ & $\begin{array}{l}-2.24 * * \\
(0.025)\end{array}$ & $\begin{array}{l}-1.61 \\
(0.108)\end{array}$ & $\begin{array}{l}-0.12 \\
(0.903)\end{array}$ & $\begin{array}{l}-1.58 \\
(0.114)\end{array}$ \\
\hline LIQ & $\begin{array}{l}4.03 * * * \\
(0.000)\end{array}$ & $\begin{array}{l}2.93 * * * \\
(0.003)\end{array}$ & $\begin{array}{l}3.70 * * * \\
(0.000)\end{array}$ & $\begin{array}{l}3.88 * * * \\
(0.000)\end{array}$ & $\begin{array}{l}2.83 * * * \\
(0.005)\end{array}$ & $\begin{array}{l}3.54 * * * \\
(0.000)\end{array}$ \\
\hline COST & $\begin{array}{l}0.75 \\
(0.456)\end{array}$ & $\begin{array}{c}0.36 \\
(0.718)\end{array}$ & $\begin{array}{c}0.72 \\
(0.470)\end{array}$ & $\begin{array}{l}1.14 \\
(0.253)\end{array}$ & $\begin{array}{l}0.73 \\
(0.467)\end{array}$ & $\begin{array}{l}1.08 \\
(0.282)\end{array}$ \\
\hline GCC & $\begin{array}{l}0.69 \\
(0.490)\end{array}$ & $\begin{array}{l}0.72 \\
(0.471)\end{array}$ & $\begin{array}{c}1.74 * \\
(0.081)\end{array}$ & $\begin{array}{l}0.26 \\
(0.796)\end{array}$ & $\begin{array}{l}0.28 \\
(0.779)\end{array}$ & $\begin{array}{l}1.38 \\
(0.168)\end{array}$ \\
\hline CRS & $\begin{array}{l}-4.02 * * * \\
(0.000)\end{array}$ & $\begin{array}{l}-3.69 * * * \\
(0.000)\end{array}$ & $\begin{array}{l}-3.51 * * * \\
(0.000)\end{array}$ & $\begin{array}{l}-4.41 * * * \\
(0.000)\end{array}$ & $\begin{array}{l}-4.09 * * * \\
(0.000)\end{array}$ & $\begin{array}{l}-3.82 * * * \\
(0.000)\end{array}$ \\
\hline INFL & $\begin{array}{l}-1.15 \\
(0.252)\end{array}$ & $\begin{array}{l}-0.34 \\
(0.732)\end{array}$ & $\begin{array}{l}-1.20 \\
(0.231)\end{array}$ & $\begin{array}{l}-1.37 \\
(0.171)\end{array}$ & $\begin{array}{l}-0.63 \\
(0.532)\end{array}$ & $\begin{array}{l}-1.46 \\
(0.143)\end{array}$ \\
\hline GDPC & $\begin{array}{l}-1.34 \\
(0.179)\end{array}$ & $\begin{array}{l}-0.65 \\
(0.515)\end{array}$ & $\begin{array}{l}-1.92 * \\
(0.055)\end{array}$ & $\begin{array}{l}-0.36 \\
(0.719)\end{array}$ & $\begin{array}{l}0.35 \\
(0.729)\end{array}$ & $\begin{array}{l}-1.02 \\
(0.310)\end{array}$ \\
\hline Fixed Effect & Year & Year & Year & Year & Year & Year \\
\hline Clustering & Bank & Bank & Bank & Bank & Bank & Bank \\
\hline Intercept & $\begin{array}{l}0.15 \\
(0.878)\end{array}$ & $\begin{array}{l}-1.93 * \\
(0.054)\end{array}$ & $\begin{array}{l}-0.26 \\
(0.795)\end{array}$ & $\begin{array}{l}0.12 \\
(0.906)\end{array}$ & $\begin{array}{l}-1.87 * \\
(0.062)\end{array}$ & $\begin{array}{l}-0.19 \\
(0.852)\end{array}$ \\
\hline$\chi^{2}$ & $278.34 * * *$ & $363.05 * * *$ & $170.64 * * *$ & $279.81 * * *$ & $351.21 * * *$ & $173.54 * * *$ \\
\hline R-squared & 0.412 & 0.485 & 0.280 & $279.81 * * *$ & 351.21 *** & $173.54 * * *$ \\
\hline No. of obs. & 0.412 & 0.485 & 0.280 & 0.416 & 0.477 & 0.286 \\
\hline
\end{tabular}

Notes: This table reports the random-effects 2SLS for panel-data regression model (EC2SLS). This table presents the following variables: unweighted/ weighted operational risk disclosure (ORD), SSB existence (SSBE), SSB members (SSBM), SSB meetings ( $S S B T)$, board size (BOSZ), non-executive directors ( $N E D S)$, block ownership $(B L C K)$, political stability and absence of violence/terrorism $(P S)$ regulatory quality $(R Q)$, bank size $(S I Z E)$, performance $(R O A)$, income diversity (INCD), liquidity $(L I Q)$, operations efficiency (COST), Gulf Cooperation Council (GCC), inflation (INFL), and GDP per capita (GDPC). Table 4 fully defines all the variables used. 
Table 10: The impact of SSBs and governance structures on ORDs using GMM model

\begin{tabular}{|c|c|c|c|c|c|c|}
\hline \multirow[t]{2}{*}{ Variables } & \multicolumn{3}{|c|}{ Dependent variable: Unweighted ORDs } & \multicolumn{3}{|c|}{ Dependent variable: Weighted ORDs } \\
\hline & (1) & (2) & (3) & (4) & (5) & (6) \\
\hline \multicolumn{7}{|c|}{ Panel A: Islamic Governance (Sharia Supervisory Board) } \\
\hline Lag ORDs & $\begin{array}{l}12.40 * * * \\
(0.000)\end{array}$ & $\begin{array}{l}10.24 * * * \\
(0.000)\end{array}$ & $\begin{array}{l}18.80 * * * \\
(0.000)\end{array}$ & $\begin{array}{l}13.19 * * * \\
(0.000)\end{array}$ & $\begin{array}{l}9.93^{* * * *} \\
(0.000)\end{array}$ & $\begin{array}{l}18.57^{* * * *} \\
(0.000)\end{array}$ \\
\hline SSBE & $\begin{array}{l}4.30 * * * \\
(0.000)\end{array}$ & & & $\begin{array}{l}5.32 * * * \\
(0.000)\end{array}$ & & \\
\hline SSBM & & $\begin{array}{l}7.49 * * * \\
(0.000)\end{array}$ & & & $\begin{array}{l}4.48 * * * \\
(0.000)\end{array}$ & \\
\hline SSBT & & & $\begin{array}{l}0.61 \\
(0.546) \\
\end{array}$ & & & $\begin{array}{l}1.67 \\
(0.101) \\
\end{array}$ \\
\hline \multicolumn{7}{|c|}{ Panel B: Governance Structures } \\
\hline BLCK & $\begin{array}{l}0.07 \\
(0.948)\end{array}$ & $\begin{array}{c}1.81^{*} \\
(0.076)\end{array}$ & $\begin{array}{l}0.64 \\
(0.525)\end{array}$ & $\begin{array}{l}0.24 \\
(0.808)\end{array}$ & $\begin{array}{l}0.02 \\
(0.985)\end{array}$ & $\begin{array}{l}2.16^{* * *} \\
(0.035)\end{array}$ \\
\hline BOSZ & $\begin{array}{l}-3.81 * * * \\
(0.000)\end{array}$ & $\begin{array}{l}-1.51 \\
(0.136)\end{array}$ & $\begin{array}{l}-2.70 * * * \\
(0.009)\end{array}$ & $\begin{array}{l}-3.80 * * * \\
(0.000)\end{array}$ & $\begin{array}{l}-4.83 * * * \\
(0.000)\end{array}$ & $\begin{array}{l}-4.42 * * * \\
(0.000)\end{array}$ \\
\hline NEDs & $\begin{array}{l}2.77 * * * \\
(0.007)\end{array}$ & $\begin{array}{l}1.77 * \\
(0.083)\end{array}$ & $\begin{array}{l}0.80 \\
(0.427)\end{array}$ & $\begin{array}{l}1.18 \\
(0.241)\end{array}$ & $\begin{array}{l}2.69 * * * \\
(0.009)\end{array}$ & $\begin{array}{l}0.20 \\
(0.841)\end{array}$ \\
\hline \multicolumn{7}{|c|}{ Panel C: Country-level Governance } \\
\hline CLG & $\begin{array}{l}7.14 * * * \\
(0.000)\end{array}$ & $\begin{array}{l}5.85^{* * * *} \\
(0.000)\end{array}$ & $\begin{array}{l}7.50 * * * \\
(0.000)\end{array}$ & $\begin{array}{l}6.62 * * * \\
(0.000)\end{array}$ & $\begin{array}{l}3.38^{* * * *} \\
(0.001)\end{array}$ & $\begin{array}{l}6.08^{* * * *} \\
(0.000)\end{array}$ \\
\hline \multicolumn{7}{|c|}{ Panel D: Control Variables } \\
\hline SIZE & $\begin{array}{l}3.52 * * * \\
(0.001)\end{array}$ & $\begin{array}{l}2.99 * * * \\
(0.004)\end{array}$ & $\begin{array}{l}4.05^{* * * *} \\
(0.000)\end{array}$ & $\begin{array}{l}3.22 * * * \\
(0.002)\end{array}$ & $\begin{array}{l}3.87^{* * * *} \\
(0.000)\end{array}$ & $\begin{array}{l}4.76^{* * * *} \\
(0.000)\end{array}$ \\
\hline ROA & $\begin{array}{l}0.40 \\
(0.694)\end{array}$ & $\begin{array}{l}1.36 \\
(0.179)\end{array}$ & $\begin{array}{l}1.36 \\
(0.178)\end{array}$ & $\begin{array}{l}1.35 \\
(0.183)\end{array}$ & $\begin{array}{l}3.08^{* * *} \\
(0.003)\end{array}$ & $\begin{array}{l}3.27^{* * *} \\
(0.002)\end{array}$ \\
\hline INCD & $\begin{array}{l}-0.74 \\
(0.465)\end{array}$ & $\begin{array}{l}-0.51 \\
(0.162)\end{array}$ & $\begin{array}{l}-0.92 \\
(0.362)\end{array}$ & $\begin{array}{l}-1.33 \\
(0.189)\end{array}$ & $\begin{array}{l}-1.51 \\
(0.137)\end{array}$ & $\begin{array}{l}-0.37 \\
(0.710)\end{array}$ \\
\hline LIQ & $\begin{array}{l}5.71 * * * \\
(0.000)\end{array}$ & $\begin{array}{l}6.44 * * * \\
(0.000)\end{array}$ & $\begin{array}{l}9.47 * * * \\
(0.000)\end{array}$ & $\begin{array}{l}5.41 \text { **** } \\
(0.000)\end{array}$ & $\begin{array}{l}6.43^{* * *} \\
(0.000)\end{array}$ & $\begin{array}{l}7.99 * * * \\
(0.000)\end{array}$ \\
\hline COST & $\begin{array}{l}0.11 \\
(0.917)\end{array}$ & $\begin{array}{l}0.28 \\
(0.784)\end{array}$ & $\begin{array}{c}2.27 * * \\
(0.027)\end{array}$ & $\begin{array}{l}0.57 \\
(0.573)\end{array}$ & $\begin{array}{l}0.44 \\
(0.659)\end{array}$ & $\begin{array}{l}3.00^{* * *} \\
(0.004)\end{array}$ \\
\hline GCC & $\begin{array}{l}5.08 * * * \\
(0.000)\end{array}$ & $\begin{array}{l}7.70^{* * *} \\
(0.000)\end{array}$ & $\begin{array}{l}3.36 * * * \\
(0.001)\end{array}$ & $\begin{array}{l}5.79^{* * * *} \\
(0.000)\end{array}$ & $\begin{array}{l}5.32 * * * \\
(0.000)\end{array}$ & $\begin{array}{l}5.00^{* * *} \\
(0.000)\end{array}$ \\
\hline CRS & $\begin{array}{l}-1.53 \\
(0.131)\end{array}$ & $\begin{array}{l}-1.81^{*} \\
(0.076)\end{array}$ & $\begin{array}{l}-0.02 \\
(0.985)\end{array}$ & $\begin{array}{l}-1.66 \\
(0.102)\end{array}$ & $\begin{array}{l}-2.10 * * \\
(0.040)\end{array}$ & $\begin{array}{l}-0.86 \\
(0.396)\end{array}$ \\
\hline INFL & $\begin{array}{l}-1.41 \\
(0.164)\end{array}$ & $\begin{array}{l}-1.32 \\
(0.192)\end{array}$ & $\begin{array}{l}-2.67 * * \\
(0.010)\end{array}$ & $\begin{array}{l}-1.85^{*} \\
(0.070)\end{array}$ & $\begin{array}{l}-1.04 \\
(0.302)\end{array}$ & $\begin{array}{l}-1.30 \\
(0.200)\end{array}$ \\
\hline GDPC & $\begin{array}{l}-0.95 \\
(0.345)\end{array}$ & $\begin{array}{l}-1.80 * \\
(0.077)\end{array}$ & $\begin{array}{l}-0.89 \\
(0.378)\end{array}$ & $\begin{array}{l}-1.70^{*} \\
(0.095)\end{array}$ & $\begin{array}{l}-3.06 * * * * \\
(0.003)\end{array}$ & $\begin{array}{l}-0.54 \\
(0.592)\end{array}$ \\
\hline Fixed Effect & Year & Year & Year & Year & Year & Year \\
\hline Clustering & Bank & Bank & Bank & Bank & Bank & Bank \\
\hline Intercept & $\begin{array}{c}2.26^{* *} \\
(0.028)\end{array}$ & $\begin{array}{l}0.73 \\
(0.470)\end{array}$ & $\begin{array}{l}3.16^{* * * *} \\
(0.002)\end{array}$ & $\begin{array}{c}2.17 * * \\
(0.034)\end{array}$ & $\begin{array}{l}1.68^{*} \\
(0.099)\end{array}$ & $\begin{array}{l}3.54 * * * \\
(0.001)\end{array}$ \\
\hline F-value & $3536 * * *$ & $1399 * * *$ & $2428 * * *$ & $2112 * * *$ & $1658^{* * * *}$ & $7067 * * *$ \\
\hline No. of obs. & 353 & 353 & 353 & 353 & 353 & 353 \\
\hline AR(1)-(p-value) & 0.000 & 0.001 & 0.000 & 0.001 & 0.001 & 0.000 \\
\hline $\mathrm{AR}(2)-(\mathrm{p}$-value $)$ & 0.790 & 0.758 & 0.250 & 0.934 & 0.831 & 0.450 \\
\hline Hansen test (p-value) & 0.684 & 0.554 & 0.622 & 0.772 & 0.619 & 0.689 \\
\hline
\end{tabular}

Notes: This table reports the two-step GMM model. This table presents the following variables: unweighted/ weighted operational risk disclosure $(O R D)$, SSB existence ( $S S B E)$, SSB members ( $S S B M)$, SSB meetings ( $S S B T)$, board size (BOSZ), non-executive directors $(N E D s)$, block ownership $(B L C K)$, political stability and absence of violence/terrorism $(P S)$ regulatory quality $(R Q)$, bank size $(S I Z E)$, performance $(R O A)$, income diversity $(I N C D)$, liquidity $(L I Q)$, operations efficiency $(C O S T)$, Gulf Cooperation Council $(G C C)$, inflation (INFL), and GDP per capita $(G D P C)$. Table 4 fully defines all the variables used. 